Article

\title{
Aerosol Optical Depth Retrieval over East Asia Using Himawari-8/AHI Data
}

\author{
Wenhao Zhang ${ }^{1}$ (1) , Hui Xu ${ }^{1,2, *(1)}$ and Fengjie Zheng ${ }^{1}$ \\ 1 Institute of Remote Sensing and Digital Earth, Chinese Academy of Sciences, Beijing 100101, China; \\ zhangwh@radi.ac.cn (W.Z.); zhengfj@radi.ac.cn (F.Z.) \\ 2 Earth System Science Interdisciplinary Center, University of Maryland, College Park, MD 20742, USA \\ * Correspondence: xuhui2013@radi.ac.cn; Tel.: +86-010-6483-9949
}

Received: 6 December 2017; Accepted: 16 January 2018; Published: 19 January 2018

\begin{abstract}
This paper presents a new algorithm to retrieve the aerosol optical depth (AOD) from a Himawari-8 Advanced Himawari Imager (AHI). Six typical aerosol models that derived from the long-term ground-based observations of East Asia are used in AOD retrieval. To accurately determine the surface reflectance, improved channel relationships between red, blue, and shortwave infrared (SWIR) are built up according to the infrared Normalized Difference Vegetation Index (NDVI ${ }_{\text {SWIR }}$ ). Based on the new derived aerosol models and improved channel relationships, AOD over East Asian is retrieved by using the AHI data. The results are compared with Moderate Resolution Imaging Spectroradiometer (MODIS) aerosol products (MOD04 and MYD04) and yielded a correlation coefficient lager than $0.8(R=0.87$ and 0.92 , respectively). In addition, the retrieved AOD values are also validated by ground-based measurements at 12 Aerosol Robotic Network (AERONET) locations and revealed a good agreement between them $(R=0.86)$.
\end{abstract}

Keywords: Himawari-8/AHI; aerosol optical depth; East Asia; geostationary satellite; AERONET

\section{Introduction}

Atmospheric aerosol plays a key role in the Earth's climate, radiative energy balance, and air quality [1-5]. However, its influence is not yet well understood and quantified due to its short lifetime and high temporal and spatial variability [6,7]. Polar orbit satellite instruments, such as the Moderate Resolution Imaging Spectroradiometer (MODIS), Advanced Very High Resolution Radiometer (AVHRR), Multiangle Imaging Spectroradiometer (MISR), and Ozone Monitoring Instrument (OMI) [8-14], provide us with a convenient way to detect, monitor, and quantify the aerosol properties globally $[15,16]$. However, aerosol products retrieved from these sensors have the temporal resolution of a day or longer, which is insufficient to capture the variation of aerosols at an hourly scale.

Geostationary orbit satellites monitoring the same earth view at an approximate altitude of $36,000 \mathrm{~km}$ can provide more frequent observations than Polar orbit satellites with the step time of an hour or less. Therefore, to better depict the high temporal variation of aerosol in a global view, several studies were carried out to retrieve AOD from geostationary satellite measurements. Wang et al. (2003) used the Geostationary Meteorological Satellite (GMS-5) to retrieve AOD over the west Pacific Ocean based on a one-channel $(0.67 \mu \mathrm{m})$ retrieval algorithm. The discrete ordinate radiative transfer (DISORT) calculations and 30 days of hourly observations were used. Additionally, to characterize aerosol properties that vary both in space and time, in situ and ground measurements were performed [17]. The Geostationary Operational Environmental Satellite (GOES-8) data was used to retrieve AOD over land based on a composite reflectance method $[18,19]$. This algorithm uses observations for a given Earth location over several days to determine the surface contribution, and then retrieves AOD based on Second Simulation of the Satellite Signal in the Solar Spectrum 
(6S) radiative transfer model [20]. Meanwhile, similar algorithms were used for other geostationary satellites such as the Multifunctional Transport Satellite (MTSAT-1R) and Fengyun-2D (FY2D) [21,22]. Zhang et al. (2011) developed an AOD retrieval algorithm for the GOES-12 imager by applying a modified Multi Angle Implementation of Atmospheric Correction (MAIAC) algorithm. The algorithm assumes that the surface Bidirectional Reflectance Distribution Function (BRDF) in the channel 1 of GOES is proportional to the seasonal average MODIS BRDF in the $2.1 \mu \mathrm{m}$ channel. It can retrieve surface reflectance and AOD with a half-hourly temporal resolution [23]. Besides, the Geostationary Ocean Color Imager (GOCI) was used to retrieve AOD by assuming a quickly varying aerosol and a slowly varying surface with time, named time series theory [24]. However, traditional geostationary meteorological satellites are usually equipped with only one visible channel with a wide spectral range, such as MTSAT, GMS, and FY2D. A limited number of channels, errors in estimating surface reflectance, and atmospheric properties mean that it is still a challenge to effectively retrieve AOD from geostationary satellites.

Himawari-8 is the next-generation geostationary meteorological satellite $[25,26]$. The observational bands in visible and near-infrared wavelengths of Himawari- 8 are sensitive to aerosol scattering and absorption, which is an attractive characteristic for aerosol research. Furthermore, it is located at $140.7^{\circ} \mathrm{E}$, enabling complete coverage of East Asia, where aerosol events are prevailing and aerosol is characterized by a very high concentration [27]. Consequently, Himawari-8/AHI provides a convenient method for monitoring aerosol over East Asia.

In previous work by Uesawa (2016), Himawari-8/AHI was used to derive the AOD and the product was used by the Japan Meteorological Agency (JMA) to monitor dust events in East Asia [28]. The band $3(0.64 \mu \mathrm{m})$, band4 $(0.86 \mu \mathrm{m})$, and band6 $(2.3 \mu \mathrm{m})$ were used to retrieve AOD over land. But band $1(0.47 \mu \mathrm{m})$, which is more sensitive to aerosol, was not included. In addition, according to Uesawa (2016), the surface reflectance of band $3(0.64 \mu \mathrm{m})$ is determined as a function of that of band6 $(2.3 \mu \mathrm{m})$, but the specific form of the function was not given. Moreover, the aerosol type used in the algorithm is assumed to be Asian dust, and is therefore not optimized for other aerosol types. In this paper, we proposed an improved algorithm for retrieving AOD from Himawari-8/AHI over East Asia. First, the aerosol properties of East Asia were characterized based on long-term ground-based measurements and derived six representative aerosol models. Furthermore, the relationships of red/blue and shortwave infrared (SWIR)/red surface reflectance were analyzed considering vegetation coverage variation. Then, the retrieval algorithm was introduced. Following this, six aerosol models and the new relationships were used in the improved AOD retrieval algorithm. Finally, to evaluate the retrieved results from the proposed algorithm, they were compared with MODIS AOD products and Aerosol Robotic Network (AERONET) measurements, respectively. The performance and limitations of the algorithm were also discussed. This work will provide a primary reference for the retrieval of AOD from the new generation geostationary satellites, as well as a reference for monitoring and forecasting air quality.

Section 2 describes the Himawari-8, MODIS, and AERONET data sets and introduces the proposed AOD retrieval methodology in detail. Section 3 presents the AOD retrieval test and validations with MDOIS and AERONET. Section 4 provides a discussion of retrieval and validation results. Section 5 presents a conclusion.

\section{Data and Methods}

\subsection{Data}

\subsubsection{Himawari-8 Advanced Himawari Imager (AHI)}

Himawari-8 was launched on 7 October 2014 by the Japan Meteorological Agency (JMA) and became operational on 7 July 2015. It carries an Advanced Himawari Imager with improved spectral, temporal, and radiometric resolution. The AHI is equipped with 16 observational bands from visible to infrared with a spatial resolution of $0.5-2 \mathrm{~km}$ and temporal resolution of $10 \mathrm{~min}$ (six full-disk images per hour) [26,29]. 
Table 1 shows the detailed spectral bands of AHI (source: http://www.jma-net.go.jp/msc/en/), and their corresponding channel response functions are plotted in Figure 1.

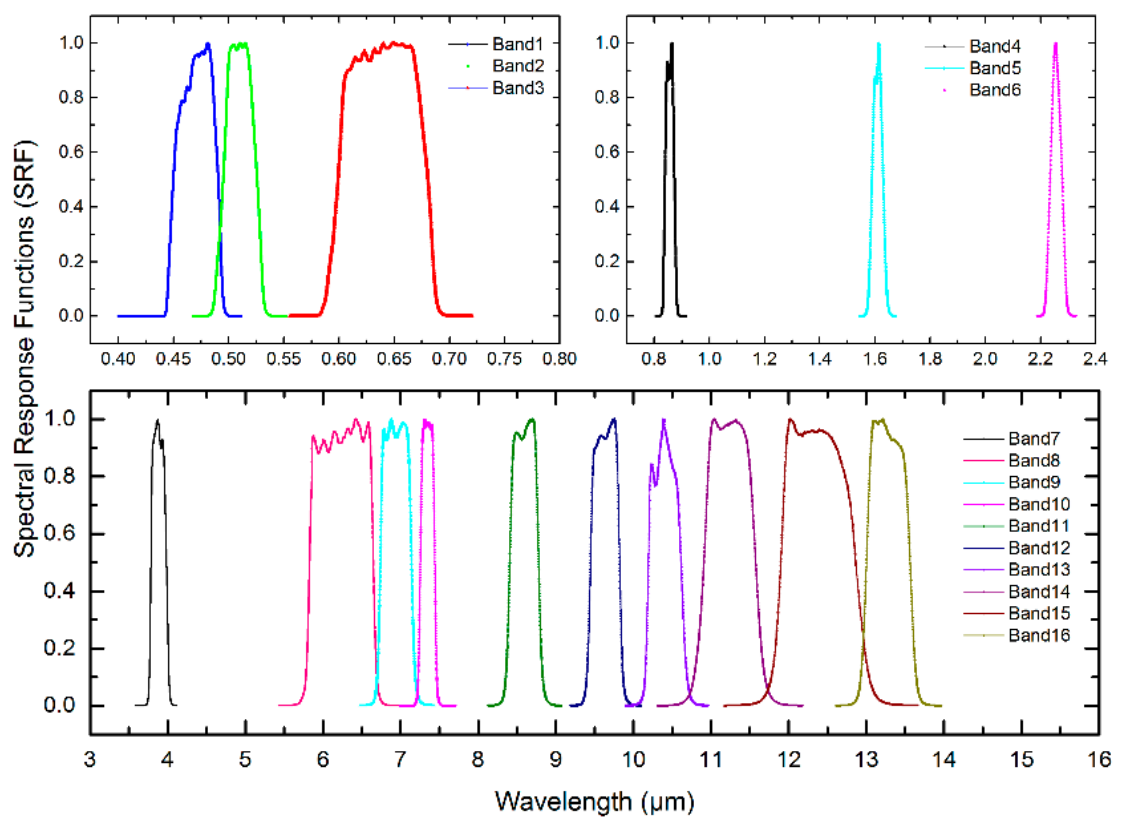

Figure 1. The spectral response functions of Himawari-8 Advanced Himawari Imager (AHI) bands.

In this paper, 17 days (15-31 October 2015) of Himawari-8 AHI data were selected. The bands of $0.455 \mu \mathrm{m}, 0.645 \mu \mathrm{m}, 1.61 \mu \mathrm{m}$, and $2.26 \mu \mathrm{m}$, with a spatial resolution $2 \mathrm{~km}$ and temporal resolution $30 \mathrm{~min}$, were used to retrieve AOD.

Table 1. Specifications of Himawari-8 Advanced Himawari Imager (AHI) spectral bands.

\begin{tabular}{|c|c|c|c|c|}
\hline Band & $\mathrm{CW}^{1}(\mu \mathrm{m})$ & $\mathrm{BW}^{2}(\mathrm{~nm})$ & Resolution at SSP ${ }^{3}$ & Prime Measurement Objectives and Use of Sample Data \\
\hline 1 & 0.455 & 50 & $1.0 \mathrm{~km}$ & Daytime aerosol over land, coastal water mapping \\
\hline 2 & 0.510 & 20 & $1.0 \mathrm{~km}$ & Green band-to produce color composite imagery \\
\hline 3 & 0.645 & 30 & $0.5 \mathrm{~km}$ & Daytime vegetation/burn scar and aerosols over water, winds \\
\hline 4 & 0.860 & 20 & $1.0 \mathrm{~km}$ & Daytime cirrus cloud \\
\hline 5 & 1.61 & 20 & $2.0 \mathrm{~km}$ & Daytime cloud-top phase and particle size, snow \\
\hline 6 & 2.26 & 20 & $2.0 \mathrm{~km}$ & Daytime land/cloud properties, particle size, vegetation, snow \\
\hline 7 & 3.85 & 220 & $2.0 \mathrm{~km}$ & Surface and cloud, fog at night, fire, winds \\
\hline 8 & 6.25 & 370 & $2.0 \mathrm{~km}$ & High-level atmospheric water vapor, winds, rainfall \\
\hline 9 & 6.95 & 120 & $2.0 \mathrm{~km}$ & Mid-level atmospheric water vapor, winds, rainfall \\
\hline 10 & 7.35 & 170 & $2.0 \mathrm{~km}$ & Lower-level water vapor, winds and $\mathrm{SO}_{2}$ \\
\hline 11 & 8.60 & 320 & $2.0 \mathrm{~km}$ & Total water for stability, cloud phase, dust, $\mathrm{SO}_{2}$, rainfall \\
\hline 12 & 9.63 & 180 & $2.0 \mathrm{~km}$ & Total ozone, turbulence, winds \\
\hline 13 & 10.45 & 300 & $2.0 \mathrm{~km}$ & Surface and cloud \\
\hline 14 & 11.20 & 200 & $2.0 \mathrm{~km}$ & Imagery, SST, clouds, rainfall \\
\hline 15 & 12.35 & 300 & $2.0 \mathrm{~km}$ & Total water, ash, SST \\
\hline 16 & 13.30 & 200 & $2.0 \mathrm{~km}$ & Air temperature, cloud heights and amounts \\
\hline
\end{tabular}

${ }^{1} \mathrm{CW}$ : Central wavelength; ${ }^{2}$ BW: Bandwidth; ${ }^{3}$ SSP: Sub Satellite Point.

\subsubsection{Moderate Resolution Imaging Spectroradiometer (MODIS)}

MODIS is a key instrument of the NASA EOS (Earth Observing System). It was launched onboard the Terra on 18 December 1999 and Aqua on 4 May 2002 [30]. Terra descends southwards in the morning (local time 10:30 a.m.) and Aqua ascends northwards in the afternoon (the local time 1:30 p.m.), respectively. The MODIS has 36 spectral bands with a wavelength that ranges from 0.4 to $14.2 \mu \mathrm{m}$, which can provide abundant information on atmospheric and terrestrial environments. The MODIS is a cross-track scanning radiometer with a two-side scan mirror which rotates over a scan 
angle range of $\pm 55^{\circ}$, producing a swath of $2330 \mathrm{~km}$ in the scan direction and $10 \mathrm{~km}$ in the track direction with each scan [31].

The MODIS AOD used in this paper was a level-2 C006 aerosol product (MOD04 for Terra and MYD04 for Aqua) with a resolution of $10 \mathrm{~km}$ (at nadir), which can be obtained from the Atmosphere Archive and Distribution System (LAADS) server (https:/ /ladsweb.nascom.nasa.gov/search/).

\subsubsection{Aerosol Robotic Network (AERONET)}

The AERONET is a global network of ground-based CIMEL sun-sky radiometers consisting of more than 700 permanent and temporary sites worldwide [32,33]. The CIMEL Sun radiometers are used for direct Sun measurements, which create a record of AOD every $15 \mathrm{~min}$ at 340, 380, 440, 500, 675, 870, and 1020 nm [34,35]. In this study, AERONET “All Points" Level 2.0 Version 2 direct Sun measurement AOD products at 12 sites, located in East Asia, were selected to compare with Himawari-8 retrieved AOD. The data can be obtained from http:/ / aeronet.gsfc.nasa.gov/. Table 2 and Figure 2 summarize detailed information of the selected AERONET sites.

Table 2. Information of the Selected AERONET Sites.

\begin{tabular}{ccccc}
\hline Number & AERONET Sites & $\begin{array}{c}\text { Longitude } \\
\text { (degree) }\end{array}$ & $\begin{array}{c}\text { Latitude } \\
\text { (degree) }\end{array}$ & $\begin{array}{c}\text { Elevation } \\
\text { (meter) }\end{array}$ \\
\hline 1 & Beijing & 116.381 & 39.977 & 92 \\
2 & Beijing-CAMS & 116.317 & 39.933 & 106 \\
3 & XiangHe & 116.962 & 39.754 & 36 \\
4 & Hong_Kong_Sheung & 114.117 & 22.483 & 40 \\
5 & Taipei_CWB & 121.5 & 25.03 & 26 \\
6 & Chen-Kung_Univ & 120.217 & 23 & 50 \\
7 & Hankuk_UFS & 127.266 & 37.339 & 167 \\
8 & Yonsei_University & 126.935 & 37.564 & 88 \\
9 & Anmyon & 126.33 & 36.539 & 47 \\
10 & Shirahama & 135.357 & 33.693 & 10 \\
11 & Osaka & 135.591 & 34.651 & 50 \\
12 & Noto & 137.137 & 37.334 & 200 \\
\hline
\end{tabular}

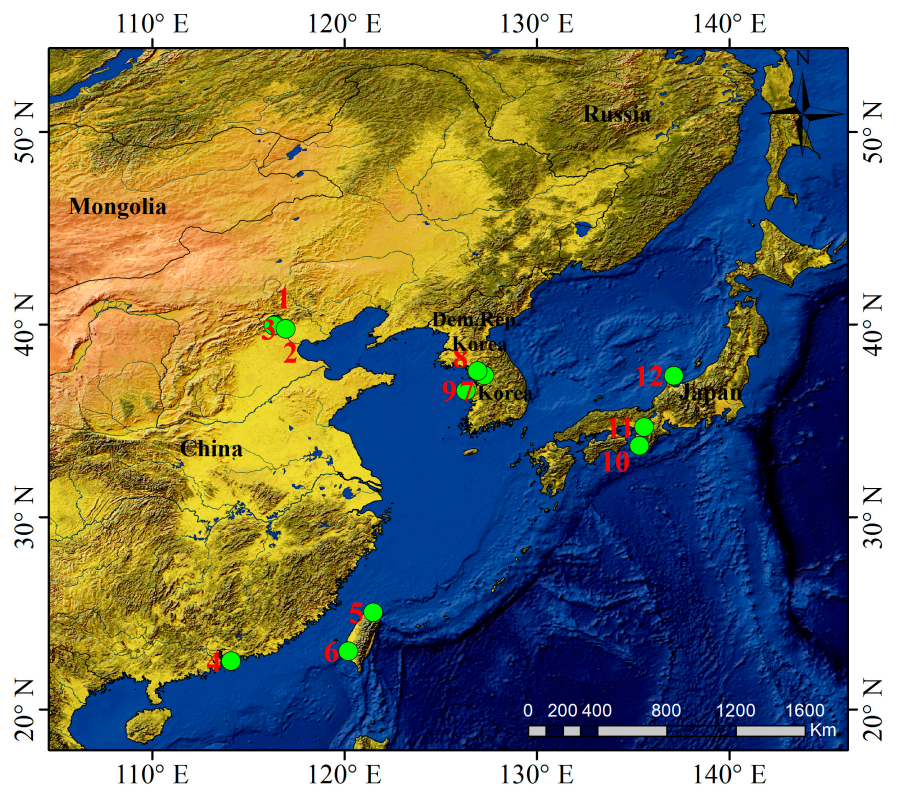

Figure 2. Locations of the selected 12 AERONET sites (green circle) used for the validation of Himawari-8 retrieved AOD. The details of each site are presented in Table 2. 
It should be noted that Himawari-8 retrieved AOD is at $550 \mathrm{~nm}$, which is not available for AERONET measurements. Therefore, the AERONET AOD $(550 \mathrm{~nm})$ is converted by the method of linear interpolation in the logarithmic space between AOD and wavelengths (500 $\mathrm{nm}$ and $675 \mathrm{~nm}$ ) [36], using Ångström exponent $\alpha$, defined as:

$$
\alpha=-\frac{\ln \left(\tau_{1} / \tau_{2}\right)}{\ln \left(\lambda_{1} / \lambda_{2}\right)}
$$

where $\tau_{1}, \tau_{2}$ are AOD at bands $\lambda_{1}, \lambda_{2}$, respectively.

\subsection{Methodology}

\subsubsection{Cloud and Water Screen Method}

The cloud and water pixels identified from Himawari-8/ AHI images are removed before obtaining the AOD retrievals over land. The channels used for cloud detection are bands 3, 4, 7, 11, 14, and 15. If one of the following conditions is satisfied, the pixel is marked as cloud [37]:

$$
\begin{gathered}
\text { Band3 }>0.3 \\
\text { Band14 }- \text { Band15 }<-0.5 \\
\text { Band7 }- \text { Band11 }>\text { 10andBand } 4>0.3
\end{gathered}
$$

The water is screened based on the Normalized Difference Water Index (NDWI) [38], meanwhile assisted by the surface type dataset (available from the Himawari- 8 auxiliary dataset). If the following conditions are satisfied, the pixel is marked as water:

$$
\begin{gathered}
\text { surface_type }=\text { water } \\
(\text { Band } 2-\text { Band } 4) /(\text { Band } 2+\text { Band } 4)>0.1
\end{gathered}
$$

Figure 3 shows the cloud and water screen results for Himawari-8/AHI data on 15 October 2015 at 03:30 UTC (Coordinated Universal Time).

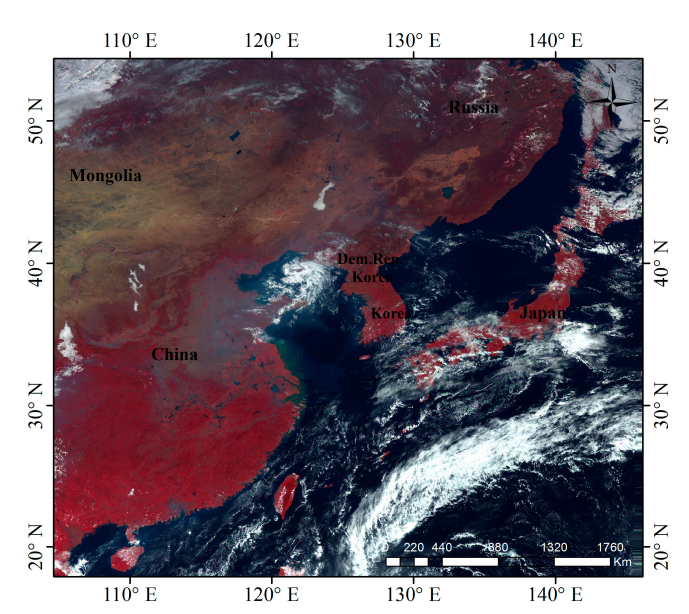

(a)

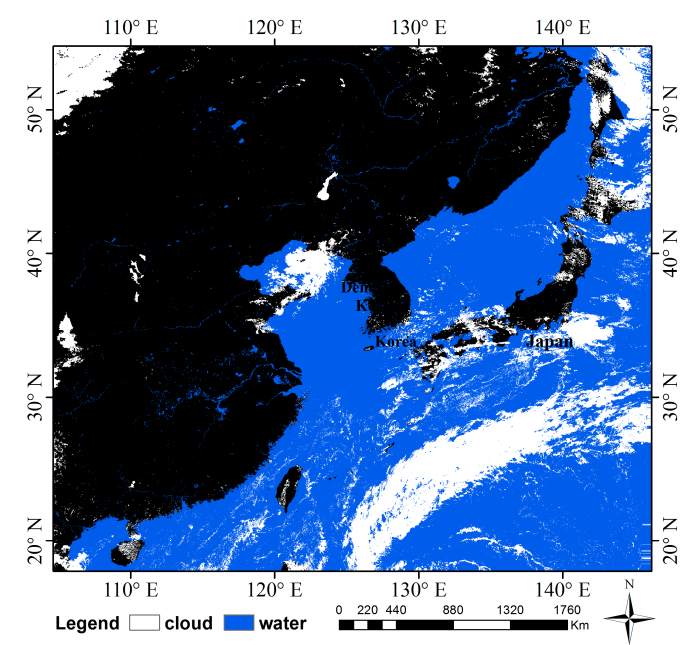

(b)

Figure 3. Cloud and water detection results. (a) False color composite of Himawari-8/AHI image (band 4, 3, and 2) on 15 October 2015 at 03:30 UTC (Coordinated Universal Time); (b) Corresponding cloud (white) and water (blue) detection results. 


\subsubsection{Aerosol Optical Properties over East Asia}

The aerosol optical properties have a significant impact on the accuracy of retrieved AOD $[39,40]$. In addition, this influence arises in regions where aerosol particles are composed of complex components and show significant spatial and temporal variability such as East Asia [41,42]. Therefore, it is crucial to understand the aerosol properties which vary from region to region, when retrieving AOD values from satellite remote sensing data.

In our previous studies, the long-term AERONET measurements (1998-2015) over East Asia were used to analyze local aerosol properties. Additionally, six representative aerosol models, which exhibit different properties, were derived based on the fuzzy clustering [43]. In this paper, these six aerosol models were used. The detailed information is summarized in Table 3, including the real/imaginary part refractive index (REFR/REFI) and parameters of particle size distributions. Figure 4 shows the phase functions and particle size distributions of six models.

Table 3. Detailed properties of six aerosol models over East Asia.

\begin{tabular}{|c|c|c|c|c|c|c|c|}
\hline \multicolumn{2}{|c|}{ Aerosol Properties } & M1 $^{1}$ & M2 & M3 & M4 & M5 & M6 \\
\hline \multirow{4}{*}{ REFR $^{2}$} & $440 \mathrm{~nm}$ & 1.42 & 1.46 & 1.40 & 1.47 & 1.50 & 1.48 \\
\hline & $676 \mathrm{~nm}$ & 1.42 & 1.46 & 1.42 & 1.50 & 1.52 & 1.51 \\
\hline & 869 nm & 1.43 & 1.47 & 1.43 & 1.51 & 1.53 & 1.51 \\
\hline & $1020 \mathrm{~nm}$ & 1.42 & 1.46 & 1.44 & 1.51 & 1.53 & 1.50 \\
\hline \multirow{4}{*}{ REFI $^{3}$} & $440 \mathrm{~nm}$ & 0.0052 & 0.0118 & 0.0079 & 0.0197 & 0.0120 & 0.0064 \\
\hline & $676 \mathrm{~nm}$ & 0.0044 & 0.0093 & 0.0061 & 0.0129 & 0.0072 & 0.0034 \\
\hline & $869 \mathrm{~nm}$ & 0.0043 & 0.0094 & 0.0059 & 0.0131 & 0.0069 & 0.0031 \\
\hline & $1020 \mathrm{~nm}$ & 0.0044 & 0.0097 & 0.0058 & 0.0136 & 0.0070 & 0.0031 \\
\hline \multicolumn{2}{|c|}{$\operatorname{VolConF}^{4}\left(\mu \mathrm{m}^{3} / \mu \mathrm{m}^{2}\right)$} & 0.13 & 0.12 & 0.10 & 0.09 & 0.08 & 0.06 \\
\hline \multicolumn{2}{|c|}{$\operatorname{EffRadF}^{5}(\mu \mathrm{m})$} & 0.25 & 0.22 & 0.18 & 0.17 & 0.17 & 0.15 \\
\hline \multicolumn{2}{|c|}{ StdDevF $^{6}$} & 0.55 & 0.55 & 0.46 & 0.50 & 0.48 & 0.51 \\
\hline \multicolumn{2}{|c|}{ VolConC $\left(\mu \mathrm{m}^{3} / \mu \mathrm{m}^{2}\right)$} & 0.07 & 0.09 & 0.08 & 0.11 & 0.15 & 0.26 \\
\hline \multicolumn{2}{|c|}{ EffRadC $(\mu \mathrm{m})$} & 2.86 & 2.78 & 2.57 & 2.73 & 2.61 & 2.25 \\
\hline \multicolumn{2}{|c|}{ StdDevC } & 0.59 & 0.59 & 0.64 & 0.64 & 0.65 & 0.61 \\
\hline
\end{tabular}

${ }^{1}$ M: aerosol model; ${ }^{2}$ REFR: Real part of refractive index; ${ }^{3}$ REFI: Imaginary part of refractive index; ${ }^{4}$ VolConF/C: volume concentration of fine/coarse modes; ${ }^{5} \mathrm{EffRadF} / \mathrm{C}$ : effective radius of fine/coarse modes; ${ }^{6} \mathrm{StdDevF}$ : standard deviation of fine/coarse modes.
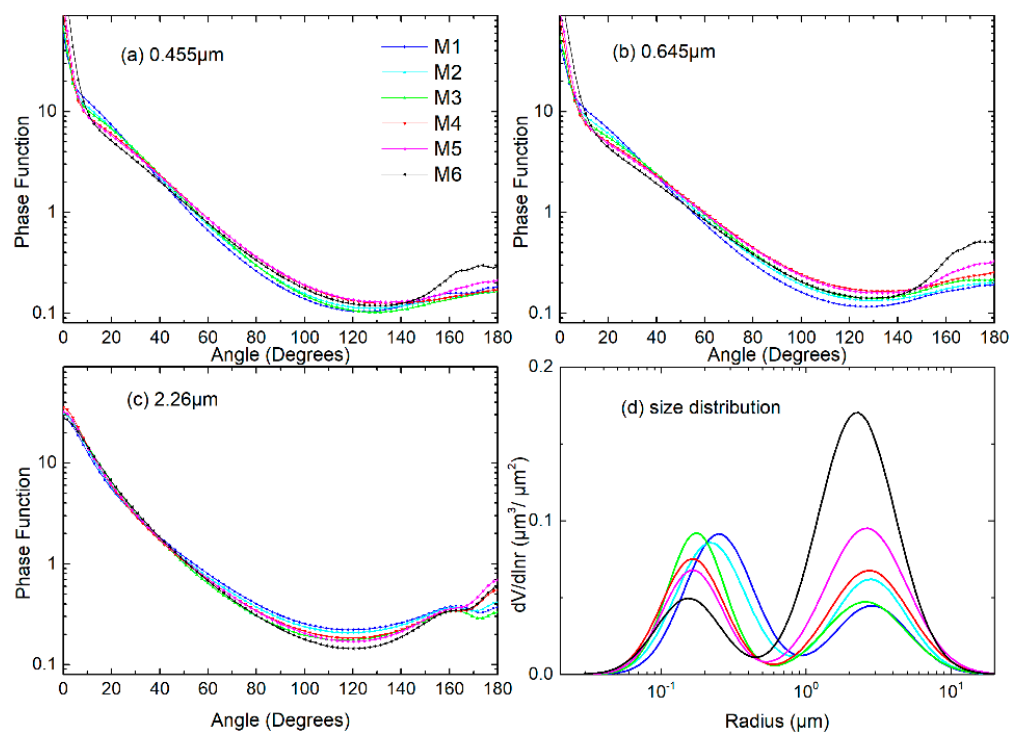

Figure 4. Plots of phase functions at (a) $0.455 \mu \mathrm{m}$; (b) $0.645 \mu \mathrm{m}$; (c) $2.26 \mu \mathrm{m}$ with AOD of 0.5 ; and (d) particle size distributions for six aerosol models. 


\subsubsection{Red/Blue and SWIR/Red Surface Reflectance Assumptions}

An accurate determination of surface reflectance is also required for satellite AOD retrieval. It has been reported that there are stable correlations between visible bands and the SWIR band at $2.1 \mu \mathrm{m}$, which has been successfully used in the MODIS AOD retrieval algorithm called Dark Dense Vegetation (DDV) or Dark Target (DT) [44,45]. However, the central wavelength of AHI SWIR is $2.26 \mu \mathrm{m}$, while the SWIR band on MODIS is $2.13 \mu \mathrm{m}$. Besides, the blue band of AHI $(0.455 \mu \mathrm{m})$ is not equal to that of MODIS $(0.469 \mu \mathrm{m})$. Furthermore, the AHI does not have channels at $1.2 \mu \mathrm{m}$ which is used to calculate infrared NDVI ${ }_{S W I R}$ (Normalized Difference Vegetation Index) to determine the dark targets in the MODIS DT algorithm. Therefore, it is necessary to establish the new relationship between visible bands and SWIR for AHI.

In order to acquire the surface reflectance of AHI, a clear sky composite method was conducted. First, the AHI images over East Asia during 15-31 October 2015 at 04:00 (UTC) were collected. Hence, there are seventeen days for each pixel (with sixteen bands). Then, for a certain pixel, the blue values of seventeen days were compared to each other. The day with the lowest blue value is identified as the clearest day for that pixel. Finally, by compositing all bands of the clearest pixels and correcting the background atmospheric effect, the surface reflectance can be determined $[21,46]$.

To correct the background atmospheric effect, we assumed that the composited pixels still had small AOD (set to be 0.05, which is the minimum of local annual observation). Pixels were also affected by Rayleigh scattering and gas absorption. First, a lookup table (LUT) was built based on a Second Simulation of the Satellite Signal in the Solar Spectrum (6S), by selecting the standard midlatitude summer atmosphere and continental aerosol model. Then, geometrical conditions (satellite and solar angle), AOD, and TOA (top of the atmosphere) reflectance were used to search LUT and interpolate the search results to obtain the surface reflectance. Figure 5 shows the composited surface reflectance of AHI at 04:00 (UTC).

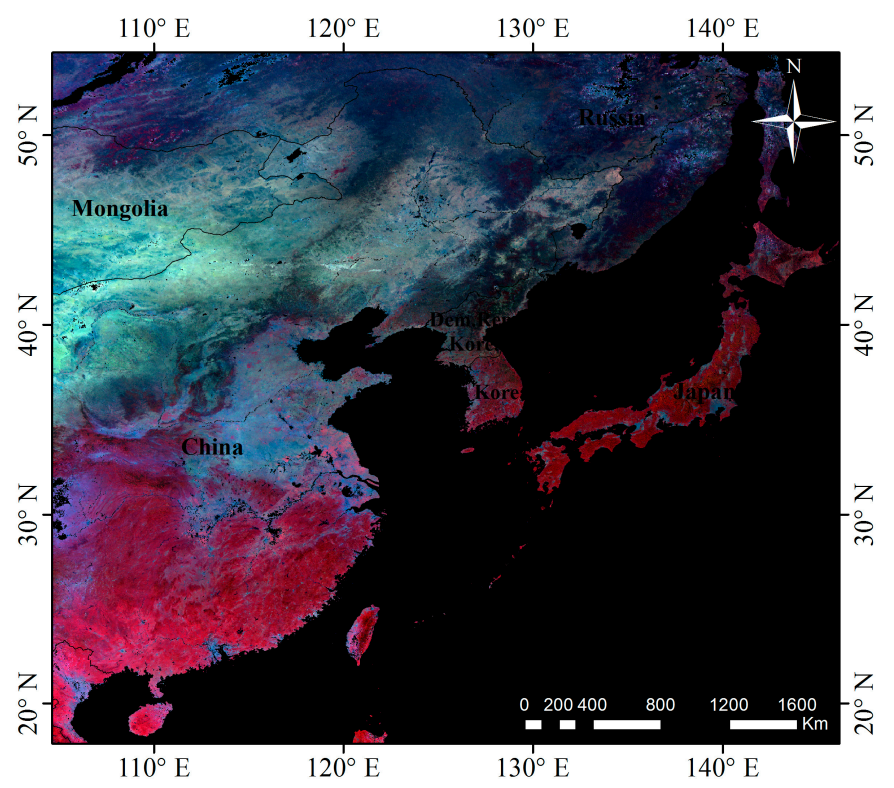

Figure 5. False color (band 4, 3, and 2) of the composited clear sky surface reflectance over East Asia during 15-31 October 2015 (the black pixels represent invalid values due to water or cloud coverage).

It has been reported that the surface reflectance relationship between visible and SWIR is not a constant. Instead, it changes with the variation of vegetation index (VI) [46]. To make the VI less sensitive to atmospheric conditions, we take the NDVI SWIR $_{\text {defined as: }}$

$$
\mathrm{NDVI}_{\text {SWIR }}=\left(\rho_{1.61}-\rho_{2.26}\right) /\left(\rho_{1.61}+\rho_{2.26}\right)
$$


where $\rho_{1.61}$ and $\rho_{2.26}$ are the surface reflectance of $1.61 \mu \mathrm{m}$ and $2.26 \mu \mathrm{m}$, respectively.

Based on the surface reflectance of clear sky, a statistical analysis of the correlation between different bands and their variations with NDVI $_{S W I R}$ was conducted. Figure 6 a plots the relationship of red $(0.645 \mu \mathrm{m})$ and blue $(0.455 \mu \mathrm{m})$ surface reflectance. Figure $6 \mathrm{~b}$ plots the relationship between SWIR $(2.26 \mu \mathrm{m})$ and red $(0.645 \mu \mathrm{m})$. It can be seen that the correlation coefficient $(\mathrm{R})$ is clearly varied with NDVI SWIR (from 0.65 to 0.89 ). Finally, the relationship of surface reflectance can be defined as a function of NDVISWIR:

$$
\rho_{\text {red }}^{s}=\rho_{\text {blue }}^{s} * \text { slop }_{0.645 / 0.455}+\text { yint }_{0.645 / 0.455}
$$

where

$$
\begin{gathered}
\text { slop }_{0.645 / 0.455}=1.393 ; \text { yint }_{0.645 / 0.455}=-0.022 ; 0<\mathrm{NDVI}_{\text {SWIR }} \leq 0.1 \\
\text { slop }_{0.645 / 0.455}=1.193 ; \text { yint }_{0.645 / 0.455}=-0.010 ; 0.1<\mathrm{NDVI}_{\text {SWIR }} \leq 0.2 \\
\text { slop }_{0.645 / 0.455}=1.147 ; \text { yint }_{0.645 / 0.455}=-0.021 ; 0.2<\mathrm{NDVI}_{\text {SWIR }} \leq 0.3 \\
\text { slop }_{0.645 / 0.455}=1.030 ; \text { yint }_{0.645 / 0.455}=-0.022 ; 0.3<\mathrm{NDVI}_{\text {SWIR }} \leq 0.4 \\
\text { slop }_{0.645 / 0.455}=0.866 ; \text { yint }_{0.645 / 0.455}=-0.015 ; 0.4<\mathrm{NDVI}_{\text {SWIR }} \leq 1 \\
\rho_{\text {SWIR }}^{s}=\rho_{\text {red }}^{s} * \text { slop }_{2.26 / 0.645}+\text { yint }_{2.26 / 0.645}
\end{gathered}
$$

where

$$
\begin{aligned}
& \text { slop }_{2.26 / 0.645}=1.788 ; \text { yint }_{2.26 / 0.645}=0.046 ; 0<\mathrm{NDVI}_{\text {SWIR }} \leq 0.1 \\
& \text { slop }_{2.26 / 0.645}=1.178 ; \text { yint }_{2.26 / 0.645}=0.011 ; 0.1<\mathrm{NDVI}_{\text {SWIR }} \leq 0.2 \\
& \text { slop }_{2.26 / 0.645}=0.956 ; \text { yint }_{2.26 / 0.645}=0.019 ; 0.2<\mathrm{NDVI}_{\text {SWIR }} \leq 1.0
\end{aligned}
$$

where $\rho_{b l u e^{\prime}}^{s} \rho_{\text {red }}^{s}$ and $\rho_{S W I R}^{s}$ are the surface reflectance of blue, red, and SWIR, respectively. We assumed that the atmosphere at SWIR was approximately transparent, hence the apparent reflectance of SWIR was used as its surface reflectance [42].

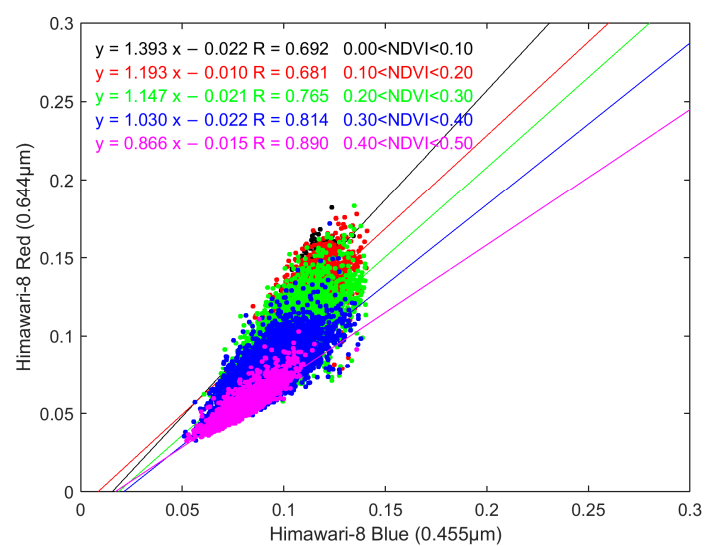

(a)

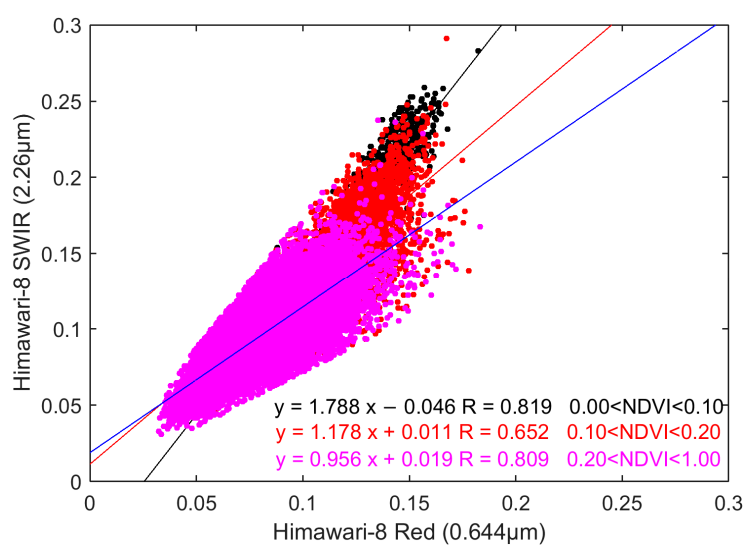

(b)

Figure 6. Surface reflectance relationships of Himawari-8 AHI bands varying with NDVI SWIR $_{\text {. }}$ (a) Red/Blue; (b) SWIR/Red.

\subsubsection{Algorithm for AOD Retrieval from Himawari-8/AHI Data}

The radiative transfer theory is the basic principle of retrieving the AOD form satellite. Based on the assumptions of the Lambertian surface and plane-parallel atmosphere, the reflectance at the top of atmosphere (TOA) can be described as [20]:

$$
\rho_{T O A}\left(\mu_{s}, \mu_{v}, \phi\right)=\rho_{0}\left(\mu_{s}, \mu_{v}, \phi\right)+\frac{T\left(\mu_{s}\right) T\left(\mu_{v}\right) \rho_{s}\left(\mu_{s}, \mu_{v}, \phi\right)}{1-S \rho_{s}\left(\mu_{s}, \mu_{v}, \phi\right)}
$$


where $\mu_{s}=\cos \left(\theta_{s}\right) ; \mu_{v}=\cos \left(\theta_{v}\right) ; \theta_{s}$, and $\theta_{s}$ are the zenith angle of the solar and satellite view, respectively; $\phi$ is the relative azimuth angle; $T\left(\mu_{s}\right)$ and $T\left(\mu_{v}\right)$ correspond to the downward and upward atmospheric transmission, respectively; $\rho_{S}$ is the surface reflectance; $\rho_{0}$ is the atmospheric path reflectance; and $S$ represents the spherical albedo of the atmosphere.

For a certain wavelength $\lambda$ :

$$
\rho_{\lambda}^{T O A}=\rho_{\lambda}^{0}+\frac{T_{\lambda} \rho_{\lambda}^{s}}{1-S_{\lambda} \rho_{\lambda}^{s}}
$$

For specified view geometry and wavelength, $\rho_{\lambda}^{0}, T_{\lambda}$, and $S_{\lambda}$ are the functions of the aerosol model and AOD. In this paper, the Second Simulation of the Satellite Signal in the Solar Spectrum (6S) was adopted to simulate TOA reflectance and calculate $\rho_{\lambda}^{0}, T_{\lambda}$, and $S_{\lambda}$. To speed up the calculation, a look-up table (LUT) was constructed. The parameters applied for LUT building are shown in Table 4 .

Table 4. The parameters used to calculate the look-up table.

\begin{tabular}{ccc}
\hline Parameters & Numbers & Values \\
\hline Wavelength & 3 & $0.455,0.645$ and $2.26 \mu \mathrm{m}$ \\
Solar zenith angle & 13 & $0,6,12, \ldots, 72\left(\right.$ step $\left.6 \mathrm{deg}{ }^{1}\right)$ \\
View zenith angle & 13 & $0,6,12, \ldots, 72$ (step 6 deg) \\
Relative azimuth & 16 & $0,12,24, \ldots, 180.0$ (step 12 deg) \\
angle & 6 & M1, M2, M3, M4, M5 and M6 \\
Aerosol model & 8 & $0,0.25,0.5,0.75,1.0,2.0,3.0$ and 5.0 \\
AOD 550 nm & \multicolumn{2}{c}{${ }^{1}$ deg: degree. }
\end{tabular}

Consequently, if the aerosol model and surface reflectance are determined, AOD can be derived by comparing measured and simulated TOA reflectance. In this study, channels of $0.455 \mu \mathrm{m}$ and $0.645 \mu \mathrm{m}$ for AHI were used to retrieve AOD. By combining Equations (5), (7), and (10), the TOA reflectance can be simulated as Equation (11).

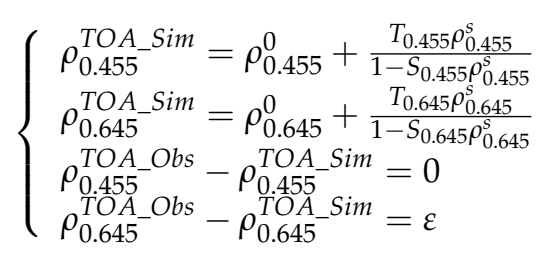

Each of the six aerosol models will obtain a value of $\varepsilon$, while the final retrieved AOD is the one where $\varepsilon$ is minimized. Figure 7 illustrates the main steps of the AOD retrieval algorithm.

The steps of the proposed algorithm are described as follows. Firstly, six aerosol models were used to build look up tables (LUTs) based on 6S. Each model had its own LUT. Then, the Himawari-8/dataset (sun-satellite geometries and bands) was preprocessed, including geometric correction and cloud-water screen. The relationship between SWIR and VIS (shown in Equations (5)-(8)) was used to estimate the surface reflectance. Secondly, the processed AHI dataset and surface reflectance were used to search and interpolate LUT on angle and AOD. Then, each model obtained a value of $\varepsilon$ and AOD. Finally, by comparing the result of each model, the one with the minimum $\varepsilon$ value was accepted as the final result. 


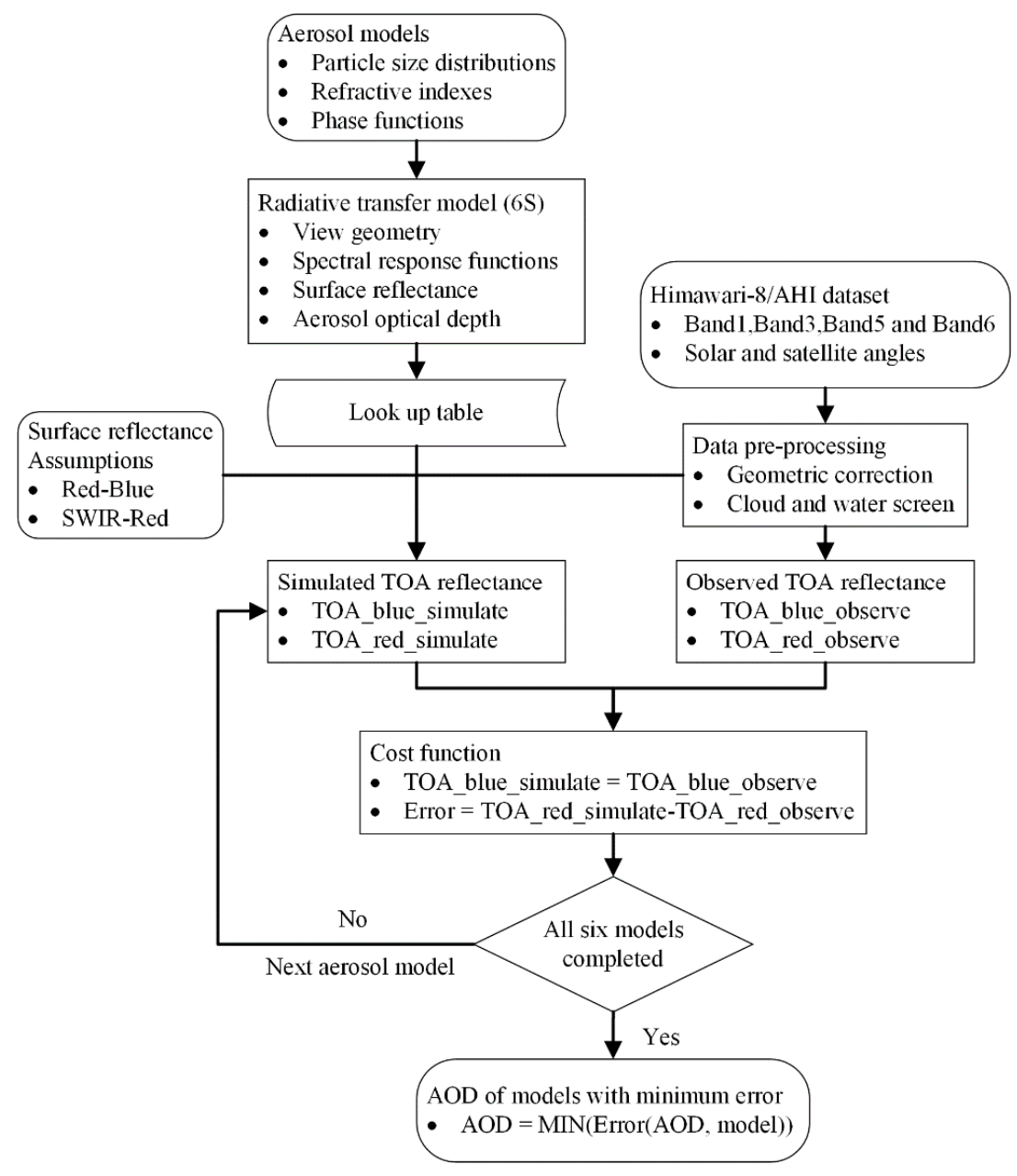

Figure 7. Flowchart of the AOD retrieval algorithm for Himawari-8/AHI data.

\section{Results}

In this section, we conducted the AOD retrieval with Himawari-8/AHI measurements based on the algorithm described in Section 2.2. Furthermore, the validation of the AOD retrieved results with MODIS Collection 6 aerosol products and AERONET ground-based observations were also executed.

\subsection{Retrieved AOD from the Proposed Algorithm}

The Himawari-8/ AHI data, during 15-31 October 2015 over East Asia, were selected to conduct AOD retrieval. It should be noted that the spatial resolution of AHI is $2.0 \mathrm{~km}$. Due to the retrieved AOD being compared with MODIS AOD products, which has a resolution of $10 \mathrm{~km}$, individual pixels are aggregated to a grid of $10 \times 10 \mathrm{~km}^{2}(5 \times 5$ pixels). Thence, the spatial resolution of the retrieved AOD is $10 \mathrm{~km}$.

Figure 8 shows the Himawari-8/ AHI image on 19 October 2015 from 03:00 (UTC) to 05:30 (UTC) with an interval of $30 \mathrm{~min}$. Figure 9 demonstrates the retrieved AOD corresponding to Figure 8. In Figure 8, it can be seen that the high loadings aerosol is prevailing over Hebei, Shandong, and Henan provinces. Moreover, the retrieved AOD had a good agreement with the AHI image in Figure 9. The result demonstrates that the proposed algorithm could obtain valid AOD over land in cloudless and waterless conditions and display the aerosol distribution very well. Besides, from the 30-min interval results, we can also study the temporal variation of AOD, which demonstrates that the aerosol loading is decreasing and moving northeast. Considering that MODIS can only overpass twice a day, AHI AOD provides more abundant details in terms of the temporal distribution. 


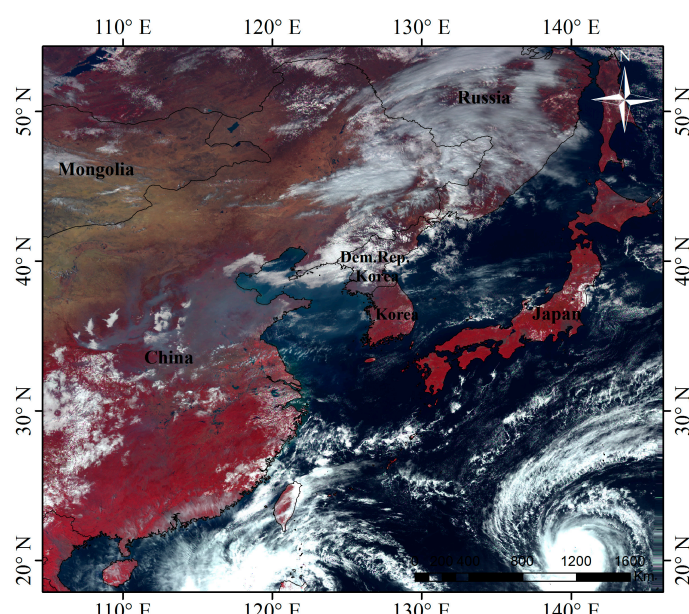

(a)

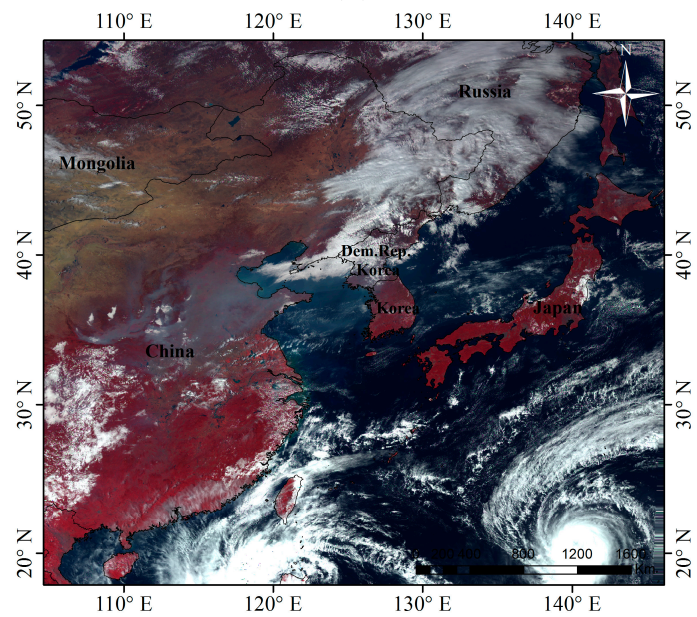

(c)

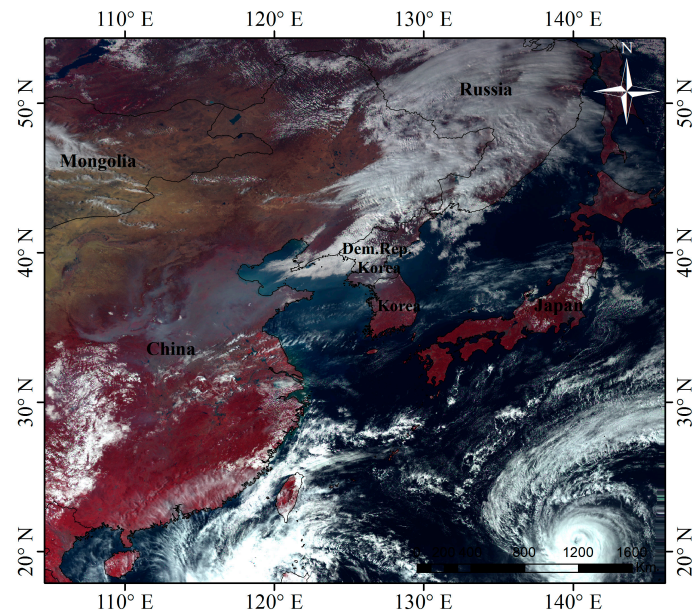

(e)

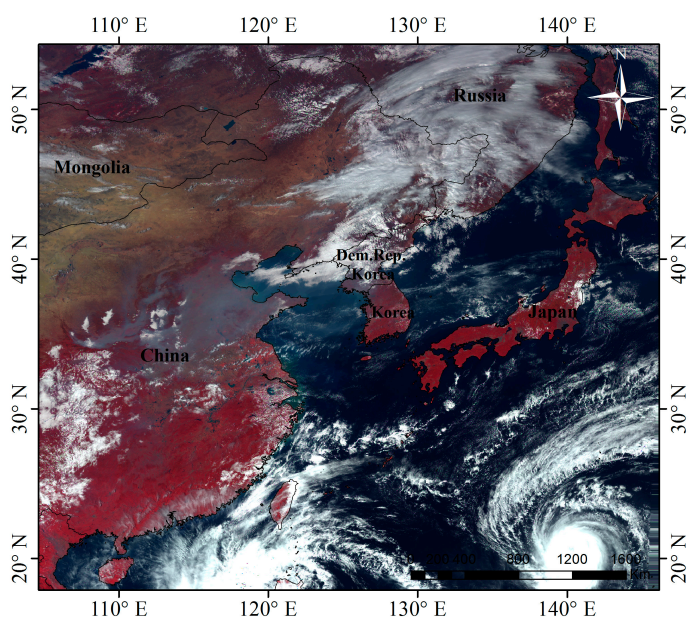

(b)

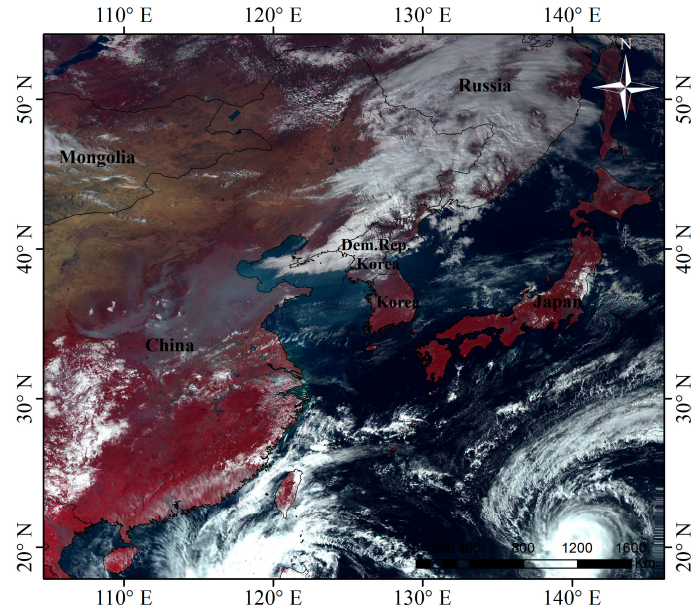

(d)

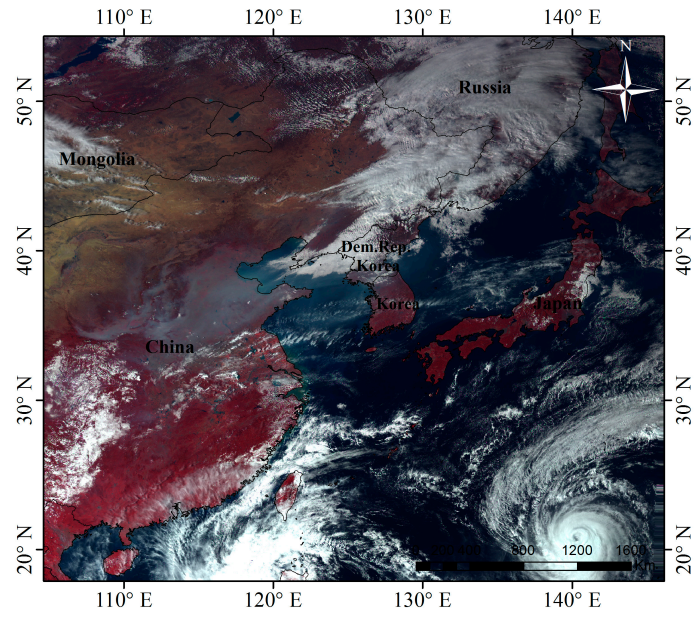

(f)

Figure 8. False color composite of Himawari-8/AHI image (band 4, 3, and 2) on 19 October 2015. (a) 03:00 (UTC); (b) 03:30 (UTC); (c) 04:00 (UTC); (d) 04:30 (UTC); (e) 05:00 (UTC); (f) 05:30 (UTC). 


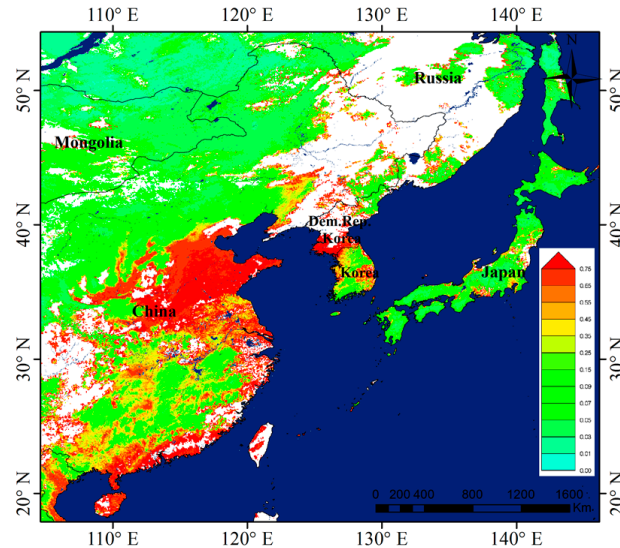

(a)

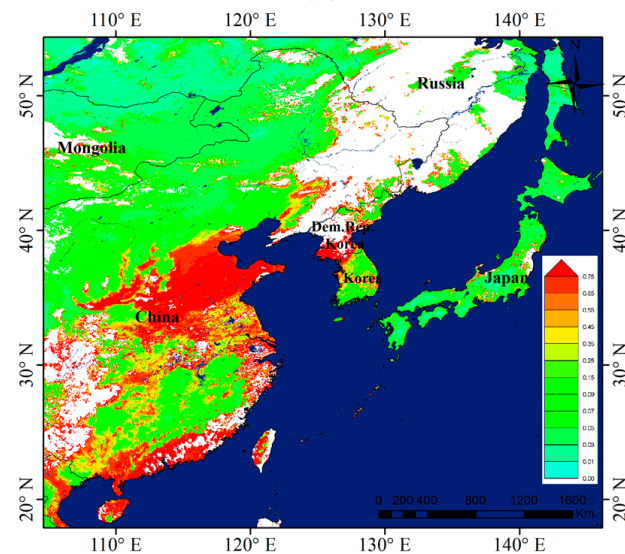

(c)

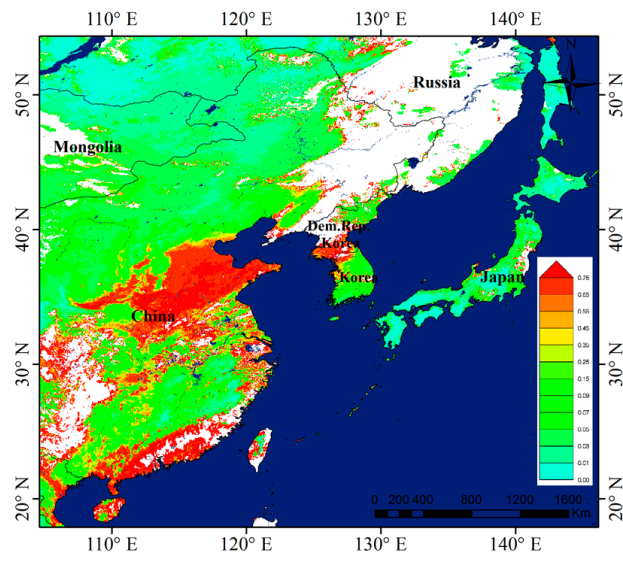

(e)

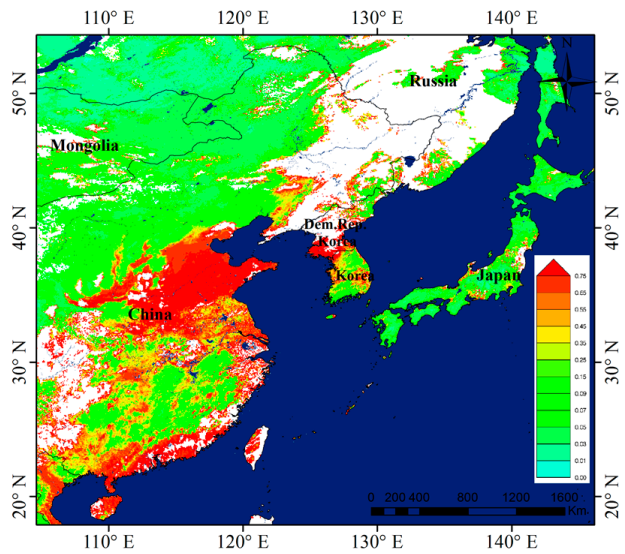

(b)

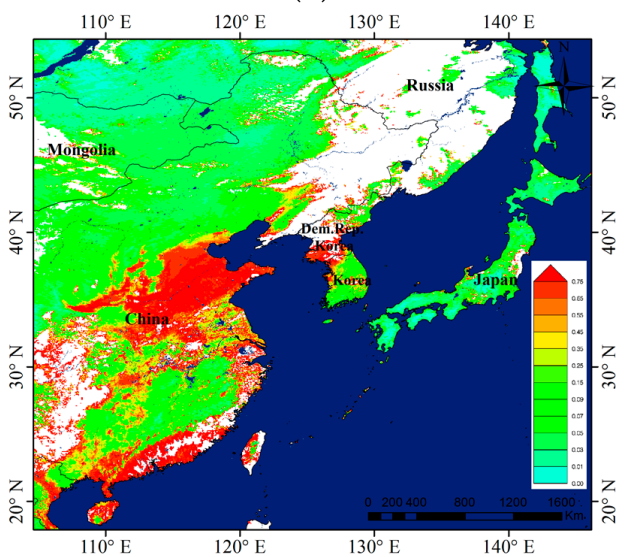

(d)

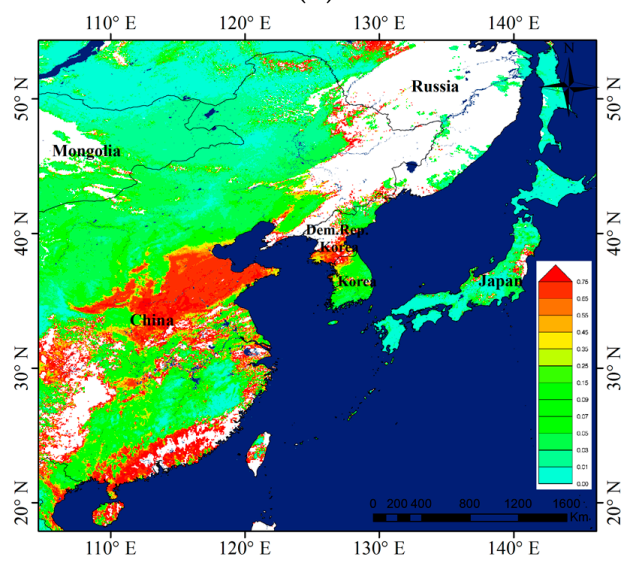

(f)

Figure 9. The AOD retrieval results from Himawari-8/AHI data on 19 October 2015. (a) 03:00 (UTC); (b) 03:30 (UTC); (c) 04:00 (UTC); (d) 04:30 (UTC); (e) 05:00 (UTC); (f) 05:30 (UTC). The pixel in blue color is water and in white color represents an invalid value. The other colors represent the value of AODs (color bar).

\subsection{Validation of Retrieved AOD with MODIS}

In this section, AHI retrieved results were compared with MODIS collection 6 aerosol products (MOD04 and MYD04). Figure 10a,b show the Himawari-8 AHI retrieved AOD on 15 October 2015 at 03:30 and 05:00 (UTC), respectively. Figure 10c is combined MOD04 at 03:20, 03:25, and 03:30 (UTC), while Figure 10d is combined MYD04 at 04:55, 05:00, and 05:05 (UTC). However, there are still places 
that failed to provide cover, which are shown as a white color in Figure 10c,d. From Figure 10c,d, we can see that high AOD values are generally distributed over Shandong and Hebei provinces.

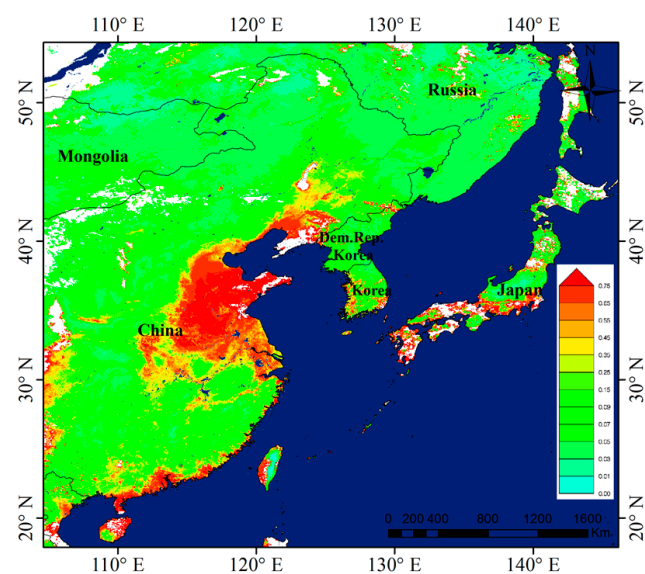

(a)

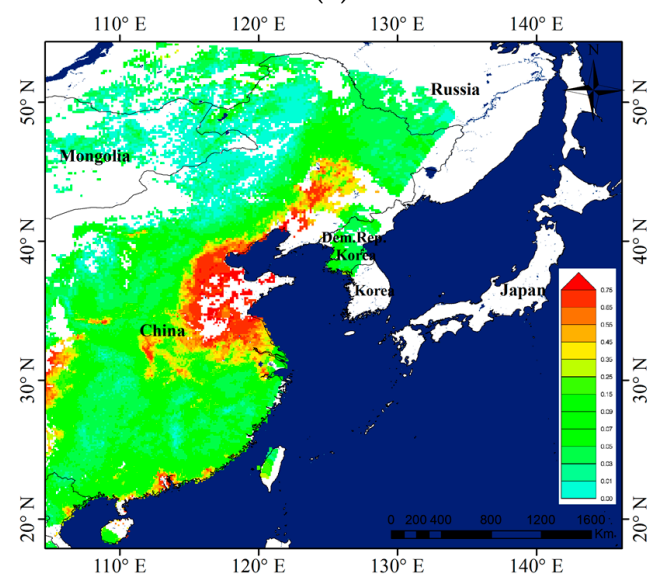

(c)

5.4

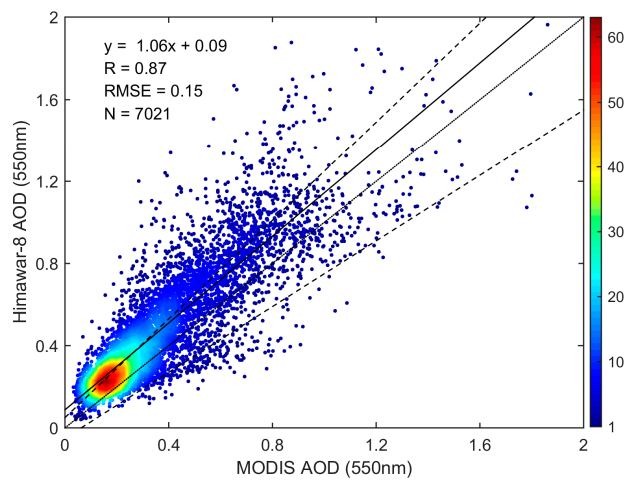

(e)

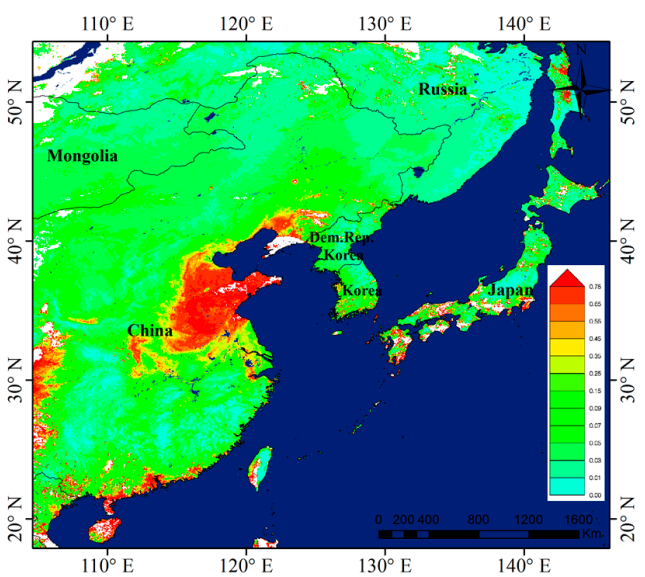

(b)

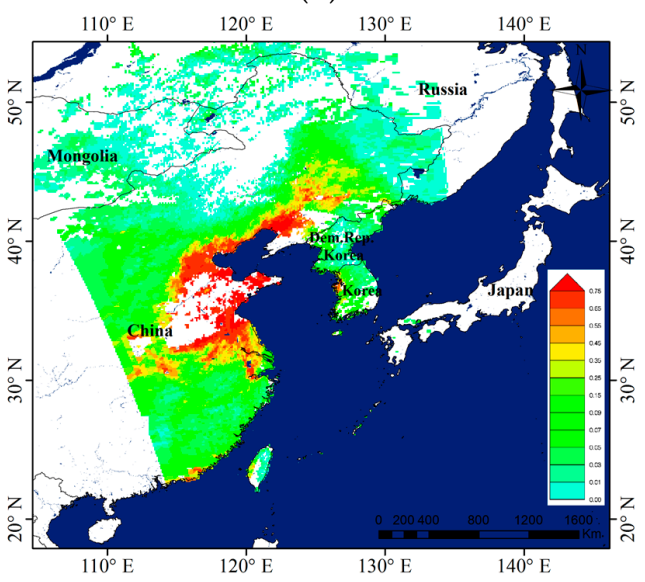

(d)

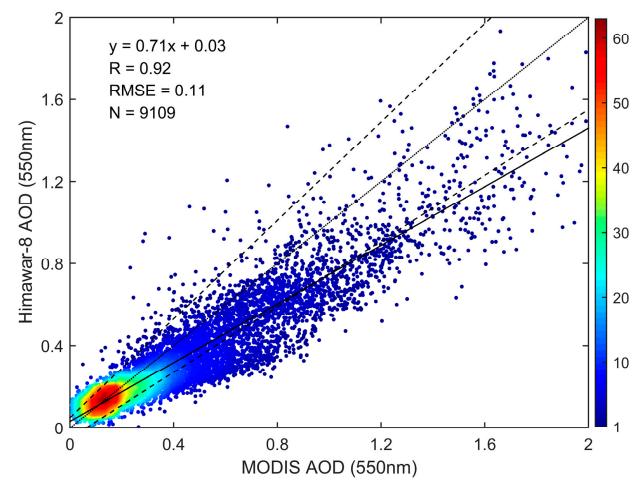

(f)

Figure 10. A comparison between the AHI retrieved AOD $(10 \mathrm{~km})$ and MODIS AOD product (MOD04/MYD04 $10 \mathrm{~km}$ ) on 15 October 2015. (a) Retrieved AOD at 03:30 (UTC); (b) Retrieved AOD at 05:00 (UTC); (c) Combined MOD04 $10 \mathrm{~km}$ at 03:20, 03:25 and 03:30 (UTC); (d) Combined MYD04 $10 \mathrm{~km}$ at 04:55, 05:00 and 05:05 (UTC); (e) Scatter plot of retrieved AOD (at 03:30) vs. MOD04 ((a) vs. (c)). Data are sorted according to ordered pairs (MOD04, retrieved AOD) of AOD in 0.02 intervals, and color represents the number of cases (color bar) with those ordered pair values; (f) Scatter plot of retrieved AOD (at 05:00) vs. MYD04 ((b) vs. (d)). The thick line represents a linear fit; dashed lines are shown as the uncertainty envelope of MODIS AOD $\left( \pm 0.05 \pm 0.15^{*} \mathrm{AOD}\right)$; the dotted line indicates the one-to-one line. 
Figure 10e shows the comparisons between AHI AOD at 03:30 and MOD04, while Figure 10f shows the comparisons between AHI AOD at 05:00 and MYD04. Both comparisons present good relationships, with correlation coefficients (R) of 0.87 and 0.92 , respectively. Additionally, both show low RMSE (root mean square errors), with values of 0.15 and 0.11 , respectively. In Figure 10e (for MOD04), the slope and $y$-axis intercept values of the regression linear fit are 1.06 and 0.09 , respectively; while in Figure 10f (for MYD04), they are 0.71 and 0.03, respectively.

\subsection{Validation of Retrieved AOD with AERONET}

There are 12 AERONET sites (shown in Table 2) over East Asia that were selected for the quantitative validation Himawari-8 AHI retrieved AOD. It is worth noting that AHI AOD for a particular pixel represents the average aerosol loading over an area intercepted by the pixel, while the AERONET observation is a point measurement. Additionally, the observation time of $\mathrm{AHI}$ and AERONET is not fully consistent. Hence, a collocation method for temporal and spatial consistency was conducted. The spatial collocation criterion is AHI AOD values that are spatially averaged in a radius of $40 \mathrm{~km}(4 \times 4$ pixels $)$ at the AERONET site. Considering that the time interval of AHI data used in this study is $30 \mathrm{~min}$, AERONET AOD values are temporally averaged in a window of $\pm 15 \mathrm{~min}$ over the satellite imaging.

The scatter plots between AERONET observed AOD and AHI retrieved AOD are shown in Figure 11. The correlation coefficient $(\mathrm{R})$ is 0.86 and RMSE is 0.12 , which indicate that the proposed algorithm has a good performance over East Asia. Moreover, the slope (1.01) of the regression linear fit is close to unity, indicating a good agreement between AHI retrieved AOD and AERONET measurements. Particularly, the $y$-axis intercept value $(0.02)$ is very small. Generally, intercept bias in the linear regression of validation can be explained by systematic uncertainty sources, such as errors in the estimation of the surface reflectance relationship.

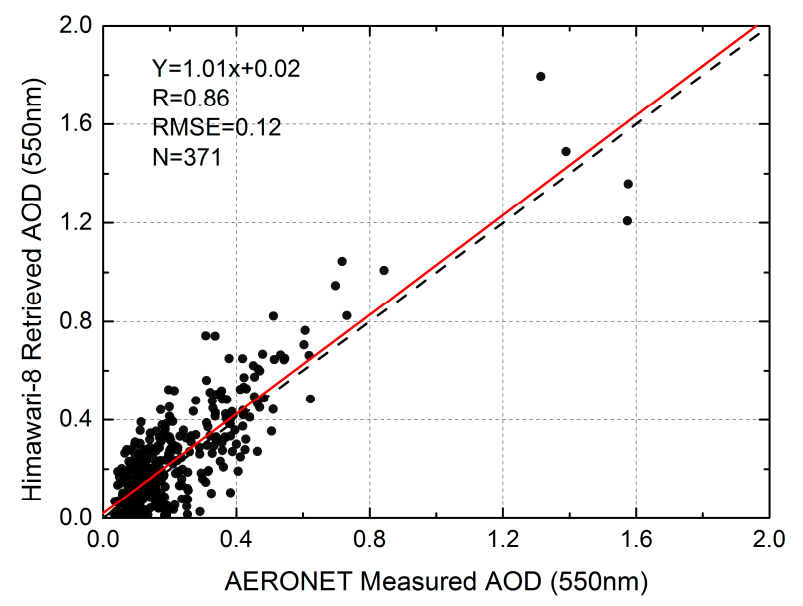

Figure 11. Comparison between the retrieved AOD and AERONET measured AOD. The red thick line represents linear fit; the dotted line indicates the one-to-one line.

To further validate the temporal consistency between AHI AOD and AERONET observations, the time series of daily average AOD comparison was performed over the three sites of Beijing, Anmyon, and Osaka. Figure 12 plots the comparison. Generally, the AHI retrieved AOD and AERONET measurements exhibit similar temporal variation trends. This indicates that AHI retrieved AOD is sufficient to reflect the temporal distribution of aerosol. 

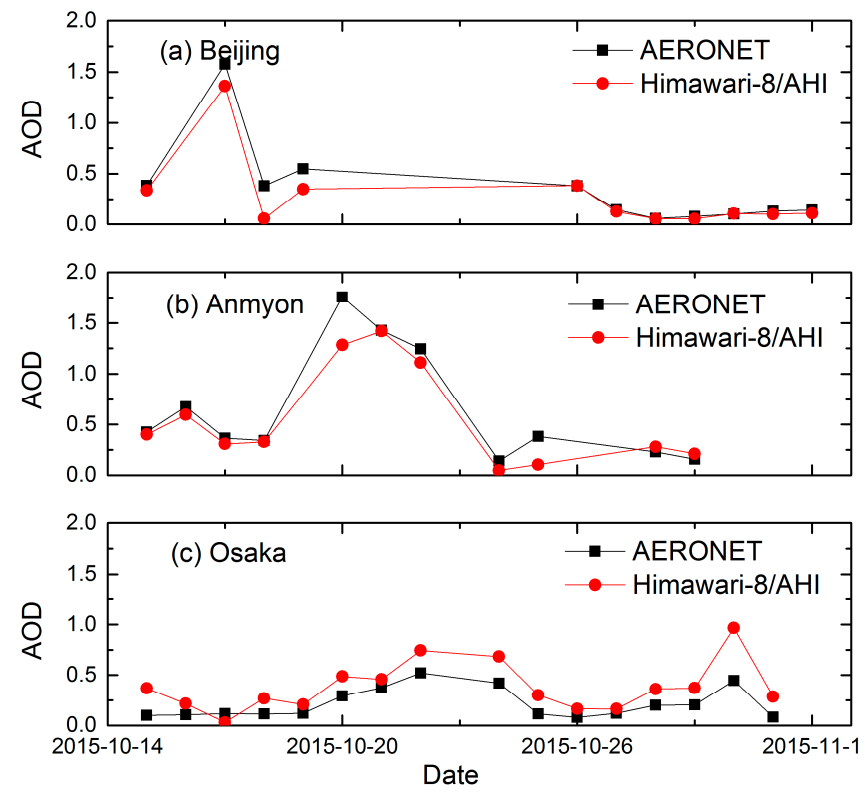

Figure 12. Time series daily average AOD from Himawari-8/AHI and AERONET measurements over three AERONET sites. (a) Beijing; (b) Anmyon; (c) Osaka.

\section{Discussion}

It is still a challenge to retrieve high temporal resolution AOD from geostationary satellites, especially for new generation geostationary satellites with a higher observation frequency and more visible channels. By making full use of both advantages of Himawari-8 AHI data, an operational AOD retrieval algorithm was proposed in this paper. The retrieved AOD had a spatial resolution of $10 \mathrm{~km}$ and temporal resolution of $30 \mathrm{~min}$, which makes it possible to capture more abundant details in the temporal distribution of aerosol than that of the MODIS AOD product (as shown in Figures 9 and 10). The retrieved Himawari-8/AHI AOD achieved a high consistency with collocated ground measurements $(\mathrm{R}=0.86$ and $\mathrm{RMSE}=0.12)$. The comparisons with MODIS product (MOD04 and MYD04) also indicate a good agreement $(\mathrm{R}=0.87$, $\mathrm{RMSE}=0.15$ and $\mathrm{R}=0.92, \mathrm{RMSE}=0.11$, respectively)

Nevertheless, the proposed algorithm tends to overestimate AOD in the comparison with MOD04 and underestimate AOD compared with MYD04. To analyze the performance of the proposed algorithm, we conducted a further discussion. Figure 13a shows the histogram of absolute differences in AOD between AHI and MODIS (AHI-MODIS). Furthermore, the red cash line represents the fitting normal distribution curve with a mean value of 0.002 and standard deviation (Std) 0.176 . Figure $13 \mathrm{~b}$ shows the absolute difference as a function of MDOIS AOD. The points and vertical lines represent the mean and one standard deviation for each AOD bin of size 0.05. The dotted lines are the expected uncertainties, $\pm 0.05 \pm 0.15 \times$ AOD, in MOD04 (MYD04). The AOD difference plot reveals that most of the mean differences remain within the expected uncertainties. It demonstrates that there is good agreement between the retrieved AHI AOD and MODIS AOD products. Nevertheless, it should be noted that with the increase of aerosol loading, the differences are slightly decreasing. It is probably due to the fact that the NDVI SWIR could be affected by large AOD, and consequently, the uncertainties of the relationship between visible and SWIR arise. To explain this, we simulated the TOA reflectance of band5 $(1.61 \mu \mathrm{m})$ and band6 $(2.26 \mu \mathrm{m})$ of AHI based on $6 \mathrm{~S}$ under different surface reflectance and AOD. As shown in Figure 14, the TOA reflectance at $1.61 \mu \mathrm{m}$ and $2.26 \mu \mathrm{m}$ increases with AOD. Therefore, the NDVISWIR calculated by these two bands (Equation (4)) could be affected by AOD. Besides, it has been reported that in heavy aerosol loading conditions, the accuracy of the MODIS AOD product decreases due to the uncertainties from the assumption of aerosol models [47]. 


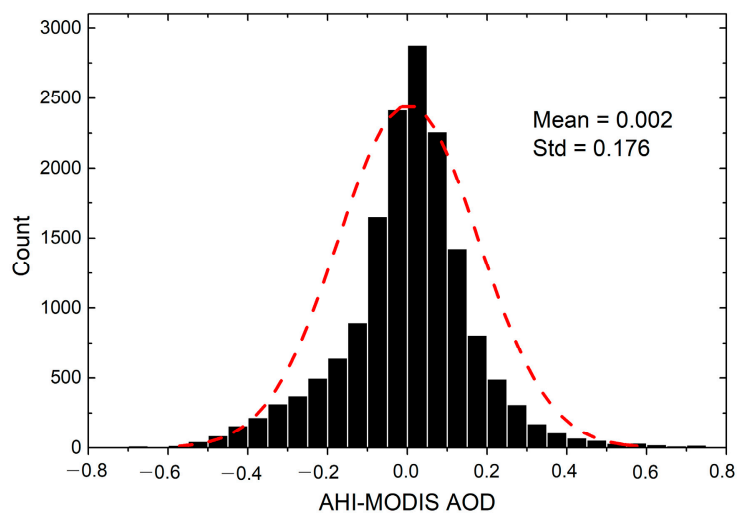

(a)

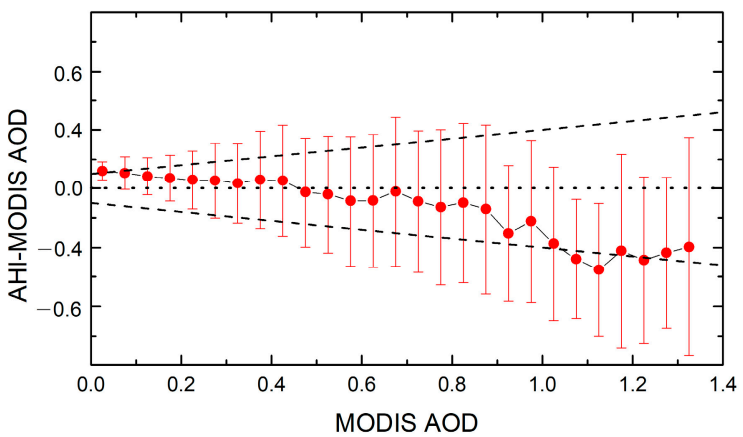

(b)

Figure 13. The absolute differences between Himawari-8/AHI retrieved AOD and MODIS AOD products (data shown in Figure 10). (a) The histogram and the fitting normal distribution curve of AHI minus MODIS; (b) The red circle represents the means of differences for each AOD bin of size 0.05, whereas the vertical lines are the associated standard deviation. The dashed lines are the expected uncertainties (top: $0.05+0.15 \times$ AOD; bottom: $-0.05-0.15 \times$ AOD) in the MODIS AOD product. The dotted line indicates no difference.
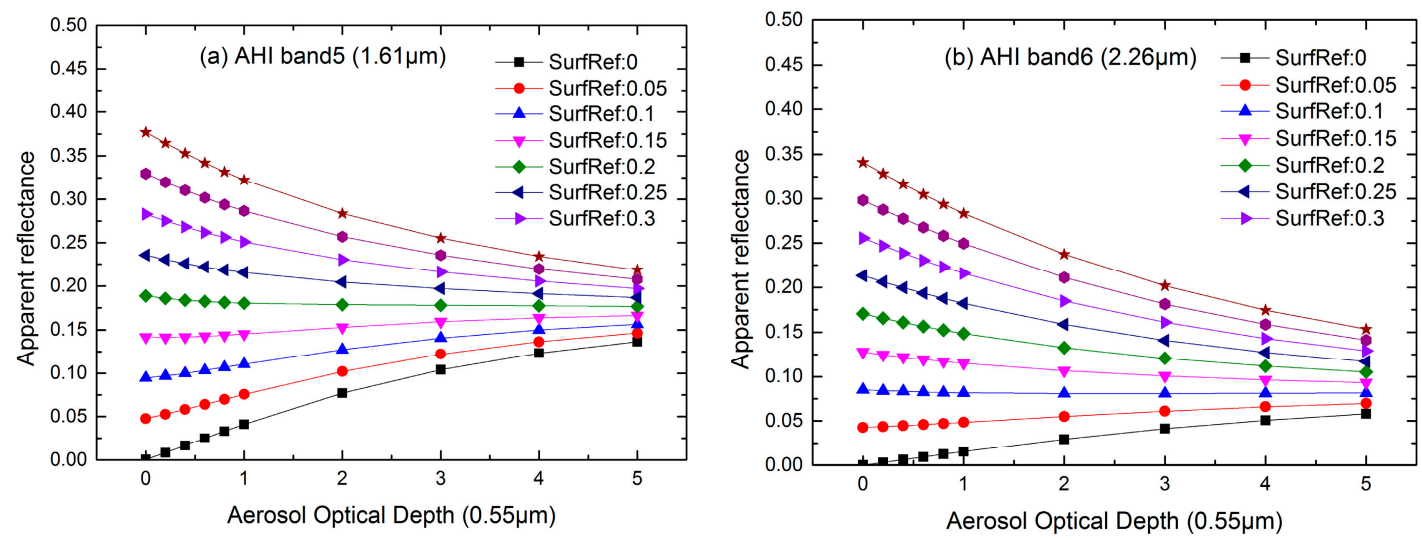

Figure 14. Himawari-8/AHI TOA reflectance at $1.61 \mu \mathrm{m}$ and $2.26 \mu \mathrm{m}$ as a function of aerosol optical depth under different surface reflectance. (a) $1.61 \mu \mathrm{m}$ (AHI band5); (b) $2.26 \mu \mathrm{m}$ (AHI band6).

\section{Conclusions}

Recently, several new generation geostationary satellites have been launched, such as Himawari-8/9, GOES-R, Gaofen-4, and Fengyun-4, which carried sensors with an improved spectral, temporal, and radiometric resolution. This provides a great convenience for atmospheric environmental monitoring.

In this study, an algorithm was proposed to retrieve AOD over East Asia from Himawari-8 AHI data with a higher temporal resolution. Six representative local aerosol models of East Asia, derived from the long-term ground-based observations, were used in AOD retrieval. Besides, to determine the contribution of surface reflectance, the relationships between the surface reflectance of AHI visible and SWIR bands were discussed. We found that both red/blue and SWIR/red have a correlation coefficient (R) that is larger than 0.65 . Additionally, the relationships varied with vegetation coverage (NDVISWIR),

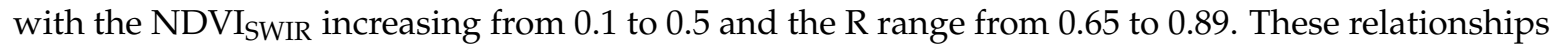
were used to retrieve AOD from AHI, and the results show that the proposed algorithm provides more abundant details in terms of the temporal distribution than the MODIS AOD product. 
A comparison of AHI retrieved AOD and MDOIS aerosol products over East Asia was carried out. The regression linear fits show correlation coefficients (R) of 0.87 and 0.92 for comparisons with MOD04 and MYD04, respectively. Furthermore, the AHI retrieved AOD was validated by ground-based measurements at 12 AERONET locations over East Asia. The correlation coefficient $(R)$ is 0.86 and RMSE is 0.12, which indicate a good agreement between AHI AOD and AERONET measurements.

However, there are still limitations of the proposed algorithm. Although a high correlation is achieved in the validation against MODIS and ground-measured AOD, a longer time range (such as one year) retrieval and validation is expected in future study. Besides, the proposed algorithm is based on the relationship between SWIR/VIS. However, the correlation coefficient (R) clearly decreases when

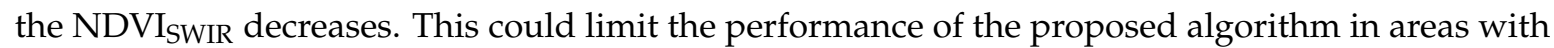
sparse vegetation. And Bidirectional Reflectance Distribution Function (BRDF) effect was found to have a potential impact on the accuracy of the algorithm. Moreover, it is still a challenge to retrieve AOD over a large view or solar zenith angle, due to lower SNR (signal-to-noise ratio). These aspects need to be further analyzed after a collection of more satellite and ground measurements in the future.

Finally, many new generation geostationary satellites have already been launched or are planning to launch. This work will provide a primary reference for the retrieval of AOD from the geostationary satellites, as well as the reference for the application of these satellites to atmospheric environment monitoring and forecasting.

Acknowledgments: This paper was supported by the National Natural Science Foundation of China (No. 41501404 and 41401422) and Satellite Load Demonstration (O890010090). The authors acknowledge MODIS data support from NASA. The authors acknowledge all the AERONET investigators for maintaining CIMEL instruments and providing high quality aerosol products. Himawari-8/AHI that was used in this paper was supplied by the P-Tree System, Japan Aerospace Exploration Agency (JAXA).

Author Contributions: Wenhao Zhang designed the research, carried out the modeling, and prepared the manuscript. All authors contributed to the scientific content, the interpretation of the results, and manuscript revisions.

Conflicts of Interest: The authors declare no conflict of interest.

\section{References}

1. Hansen, J.; Sato, M.; Ruedy, R. Radiative forcing and climate response. J. Geophys. Res. 1997, 102, 6831-6864. [CrossRef]

2. Kaufman, Y.J.; Tanré, D.; Boucher, O. A satellite view of aerosols in the climate system. Nature 2002, 419, 215-223. [CrossRef] [PubMed]

3. Andreae, M.O.; Jones, C.D.; Cox, P.M. Strong present-day aerosol cooling implies a hot future. Nature 2005, 435, 1187-1190. [CrossRef] [PubMed]

4. Yu, H.; Kaufman, Y.J.; Chin, M.; Feingold, G.; Remer, L.A.; Anderson, T.L.; Balkanski, Y.; Bellouin, N.; Boucher, O.; Christopher, S.; et al. A review of measurement-based assessments of the aerosol direct radiative effect and forcing. Atmos. Chem. Phys. 2006, 6, 613-666. [CrossRef]

5. Adler, C.E.; Hirsch Hadorn, G. The IPCC and treatment of uncertainties: Topics and sources of dissensus. Wiley Interdiscip. Rev. Clim. Chang. 2014, 5, 663-676. [CrossRef]

6. Anderson, T.L. Atmospheric Science: Climate Forcing by Aerosol-A Hazy Picture. Science 2003, 300, 1103-1104. [CrossRef] [PubMed]

7. Mishchenko, M.I.; Geogdzhayev, I.V.; Cairns, B.; Carlson, B.E.; Chowdhary, J.; Lacis, A.A.; Liu, L.; Rossow, W.B.; Travis, L.D. Past, present, and future of global aerosol climatologies derived from satellite observations: A perspective. J. Quant. Spectrosc. Radiat. Transf. 2007, 106, 325-347. [CrossRef]

8. Levy, R.C.; Mattoo, S.; Munchak, L.A.; Remer, L.A.; Sayer, A.M.; Patadia, F.; Hsu, N.C. The Collection 6 MODIS aerosol products over land and ocean. Atmos. Meas. Tech. 2013, 6, 2989-3034. [CrossRef]

9. Remer, L.A.; Mattoo, S.; Levy, R.C.; Munchak, L.A. MODIS 3 km aerosol product: Algorithm and global perspective. Atmos. Meas. Tech. 2013, 6, 1829-1844. [CrossRef]

10. Hsu, N.C.; Jeong, M.J.; Bettenhausen, C.; Sayer, A.M.; Hansell, R.; Seftor, C.S.; Huang, J.; Tsay, S.C. Enhanced Deep Blue aerosol retrieval algorithm: The second generation. J. Geophys. Res. Atmos. 2013, 118, 9296-9315. [CrossRef] 
11. Riffler, M.; Popp, C.; Hauser, A.; Fontana, F.; Wunderle, S. Validation of a modified AVHRR aerosol optical depth retrieval algorithm over Central Europe. Atmos. Meas. Tech. 2010, 3, 1255-1270. [CrossRef]

12. Shi, Y.; Zhang, J.; Reid, J.S.; Liu, B.; Hyer, E.J. Critical evaluation of cloud contamination in the MISR aerosol products using MODIS cloud mask products. Atmos. Meas. Tech. 2014, 7, 1791-1801. [CrossRef]

13. Torres, O.; Ahn, C.; Chen, Z. Improvements to the OMI near-UV aerosol algorithm using A-train CALIOP and AIRS observations. Atmos. Meas. Tech. 2013, 6, 3257-3270. [CrossRef]

14. Zhang, W.; Gu, X.; Xu, H.; Yu, T.; Zheng, F. Assessment of OMI near-UV aerosol optical depth over Central and East Asia. J. Geophys. Res. Atmos. 2016, 121, 382-398. [CrossRef]

15. Collins, W.D.; Rasch, P.J.; Eaton, B.E.; Khattatov, B.V.; Lamarque, J.-F.; Zender, C.S. Simulating aerosols using a chemical transport model with assimilation of satellite aerosol retrievals: Methodology for INDOEX. J. Geophys. Res. Atmos. 2001, 106, 7313-7336. [CrossRef]

16. Yang, J.; Gong, P.; Fu, R.; Zhang, M.; Chen, J.; Liang, S.; Xu, B.; Shi, J.; Dickinson, R. The role of satellite remote sensing in climate change studies. Nat. Clim. Chang. 2013, 3, 1001. [CrossRef]

17. Wang, J.; Christopher, S.A.; Brechtel, F.; Kim, J.; Schmid, B.; Redemann, J.; Russell, P.B.; Quinn, P.; Holben, B.N Geostationary satellite retrievals of aerosol optical thickness during ACE-Asia. J. Geophys. Res. 2003, 108, 8657. [CrossRef]

18. Knapp, K.R. Quantification of aerosol signal in GOES 8 visible imagery over the United States. J. Geophys. Res. 2002, 107, 4426. [CrossRef]

19. Knapp, K.R.; Frouin, R.; Kondragunta, S.; Prados, A. Toward aerosol optical depth retrievals over land from GOES visible radiances: Determining surface reflectance. Int. J. Remote Sens. 2005, 26, 4097-4116. [CrossRef]

20. Vermote, E.F.; Tanré, D.; Deuzé, J.L.; Herman, M.; Morcrette, J.J. Second simulation of the satellite signal in the solar spectrum, 6s: An overview. IEEE Trans. Geosci. Remote Sens. 1997, 35, 675-686. [CrossRef]

21. Mei, L.; Xue, Y.; Wang, Y.; Hou, T.; Guang, J.; Li, Y.; Xu, H.; Wu, C.; He, X.; Dong, J.; et al. Prior information supported aerosol optical depth retrieval using FY2D data. In Proceedings of the 2011 IEEE International Geoscience and Remote Sensing Symposium, Vancouver, BC, Canada, 24-29 July 2011; Volume 3, pp. 2677-2680.

22. Kim, J.; Yoon, J.-M.; Ahn, M.H.; Sohn, B.J.; Lim, H.S. Retrieving aerosol optical depth using visible and mid-IR channels from geostationary satellite MTSAT-1R. Int. J. Remote Sens. 2008, 29, 6181-6192. [CrossRef]

23. Zhang, H.; Lyapustin, A.; Wang, Y.; Kondragunta, S.; Laszlo, I.; Ciren, P.; Hoff, R.M. A multi-angle aerosol optical depth retrieval algorithm for geostationary satellite data over the United States. Atmos. Chem. Phys. 2011, 11, 11977-11991. [CrossRef]

24. Zhang, Y.; Li, Z.; Zhang, Y.; Hou, W.; Xu, H.; Chen, C.; Ma, Y. High temporal resolution aerosol retrieval using Geostationary Ocean Color Imager: Application and initial validation. J. Appl. Remote Sens. 2014, 8, 83612. [CrossRef]

25. Bessho, K.; Date, K.; Hayashi, M.; Ikeda, A.; Imai, T.; Inoue, H.; Kumagai, Y.; Miyakawa, T.; Murata, H.; Ohno, T.; et al. An Introduction to Himawari-8/9 Japan's New-Generation Geostationary Meteorological Satellites. J. Meteorol. Soc. Jpn. Ser. II 2016, 94, 151-183. [CrossRef]

26. Yumimoto, K.; Nagao, T.M.; Kikuchi, M.; Sekiyama, T.T.; Murakami, H.; Tanaka, T.Y.; Ogi, A.; Irie, H.; Khatri, P.; Okumura, H.; et al. Aerosol data assimilation using data from Himawari-8, a next-generation geostationary meteorological satellite. Geophys. Res. Lett. 2016, 43, 5886-5894. [CrossRef]

27. Luan, Y.; Jaeglé, L. Composite study of aerosol export events from East Asia and North America. Atmos. Chem. Phys. 2013, 13, 1221-1242. [CrossRef]

28. Uesawa, D. Aerosol Optical Depth Product Derived from Himawari-8 Data for Asian Dust Monitoring; Meteorological Satellite Center Technical Note; 2016; pp. 59-63. Available online: http:/ / www.data.jma.go. jp/mscweb/technotes/msctechrep61-6.pdf (accessed on 17 January 2018).

29. Lee, S.; Han, H.; Im, J.; Jang, E.; Lee, M.-I. Detection of deterministic and probabilistic convection initiation using Himawari-8 Advanced Himawari Imager data. Atmos. Meas. Tech. 2017, 10, 1859-1874. [CrossRef]

30. Barnes, W.L.; Xiong, X.; Salomonson, V.V. Status of Terra MODIS and Aqua MODIS. Adv. Space Res. 2003, 32, 2099-2106. [CrossRef]

31. Xiong, X.; Chiang, K.; Esposito, J.; Guenther, B.; Barnes, W. MODIS on-orbit calibration and characterization. Metrologia 2003, 40, S89-S92. [CrossRef] 
32. Holben, B.N.; Tanré, D.; Smirnov, A.; Eck, T.F.; Slutsker, I.; Abuhassan, N.; Newcomb, W.W.; Schafer, J.S.; Chatenet, B.; Lavenu, F.; et al. An emerging ground-based aerosol climatology: Aerosol optical depth from AERONET. J. Geophys. Res. Atmos. 2001, 106, 12067-12097. [CrossRef]

33. Holben, B.N.; Eck, T.F.; Slutsker, I.; Smirnov, A.; Sinyuk, A.; Schafer, J.; Giles, D.; Dubovik, O. Aeronet's Version 2.0 quality assurance criteria. Proc. SPIE 2006, 6408, 64080Q. [CrossRef]

34. Dubovik, O.; Smirnov, A.; Holben, B.N.; King, M.D.; Kaufman, Y.J.; Eck, T.F.; Slutsker, I. Accuracy assessments of aerosol optical properties retrieved from Aerosol Robotic Network (AERONET) Sun and sky radiance measurements. J. Geophys. Res. Atmos. 2000, 105, 9791-9806. [CrossRef]

35. Dubovik, O.; King, M.D. A flexible inversion algorithm for retrieval of aerosol optical properties from Sun and sky radiance measurements. J. Geophys. Res. Atmos. 2000, 105, 20673-20696. [CrossRef]

36. Eck, T.F.; Holben, B.N.; Reid, J.S.; Dubovik, O.; Smirnov, A.; O’Neill, N.T.; Slutsker, I.; Kinne, S. Wavelength dependence of the optical depth of biomass burning, urban, and desert dust aerosols. J. Geophys. Res. Atmos. 1999, 104, 31333-31349. [CrossRef]

37. Imai, T.; Yoshida, R. Algorithm Theoretical Basis for Himawari-8 Cloud Mask Product; Meteorological Satellite Center Technical Note; 2016; pp. 1-17. Available online: http:/ / www.data.jma.go.jp/mscweb/technotes / msctechrep61-1.pdf (accessed on 17 January 2018).

38. McFeeters, S.K. The use of the Normalized Difference Water Index (NDWI) in the delineation of open water features. Int. J. Remote Sens. 1996, 17, 1425-1432. [CrossRef]

39. Omar, A.H.; Won, J.G.; Winker, D.M.; Yoon, S.C.; Dubovik, O.; McCormick, M.P. Development of global aerosol models using cluster analysis of Aerosol Robotic Network (AERONET) measurements. J. Geophys. Res. D Atmos. 2005, 110, 1-14. [CrossRef]

40. Levy, R.C.; Remer, L.A.; Dubovik, O. Global aerosol optical properties and application to Moderate Resolution Imaging Spectroradiometer aerosol retrieval over land. J. Geophys. Res. Atmos. 2007, 112, D13210. [CrossRef]

41. Lee, K.H.; Kim, Y.J. Satellite remote sensing of Asian aerosols: A case study of clean, polluted, and Asian dust storm days. Atmos. Meas. Tech. 2010, 3, 1771-1784. [CrossRef]

42. Zhang, W. Research on the Retrieving of High Temporal Resolution Aerosol Optical Properties from Remote Sensing Data over East Asian. Ph.D Thesis, The University of Chinese Academy of Sciences, Beijing, China, 30 May 2016.

43. Zhang, W.; Xu, H.; Zheng, F. Classifying Aerosols Based on Fuzzy Clustering and Their Optical and Microphysical Properties Study in Beijing, China. Adv. Meteorol. 2017, 2017, 4197652. [CrossRef]

44. Kaufman, Y.J.; Wald, A.E.; Remer, L.A.; Gao, B.-C.; Li, R.-R.; Flynn, L. The MODIS 2.1- $\mu$ m channel-correlation with visible reflectance for use in remote sensing of aerosol. IEEE Trans. Geosci. Remote Sens. 1997, 35, 1286-1298. [CrossRef]

45. Kaufman, Y.J.; Gobron, N.; Pinty, B.; Widlowski, J.-L.; Verstraete, M.M. Relationship between surface reflectance in the visible and mid-IR used in MODIS aerosol algorithm-theory. Geophys. Res. Lett. 2002, 29. [CrossRef]

46. Fröhlich, C.; Shaw, G.E. New determination of Rayleigh scattering in the terrestrial atmosphere. Appl. Opt. 1980, 19, 1773-1775. [CrossRef] [PubMed]

47. Tao, M.; Chen, L.; Wang, Z.; Tao, J.; Che, H.; Wang, X.; Wang, Y. Comparison and evaluation of the MODIS Collection 6 aerosol data in China. J. Geophys. Res. Atmos. 2015, 120, 6992-7005. [CrossRef]

(C) 2018 by the authors. Licensee MDPI, Basel, Switzerland. This article is an open access article distributed under the terms and conditions of the Creative Commons Attribution (CC BY) license (http:/ / creativecommons.org/licenses/by/4.0/). 